\title{
Summary of the mineralogy of the Colorado Plateau uranium ores
}

By A. D. Weeks, R. G. Coleman, and M. E. Thompson

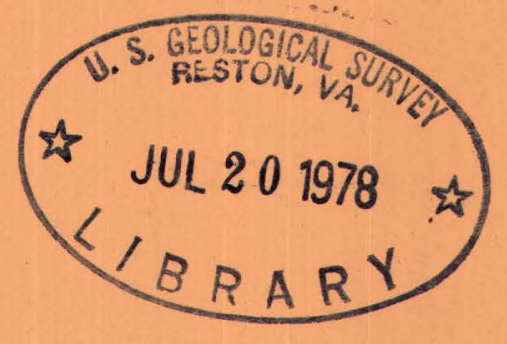

\section{Trace Elements Investigations Report 583}

UNITED STATES DEPARTMENT OF THE INTERIOR GEOLOGICAL SURVEY

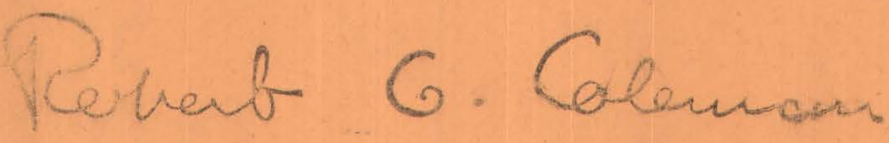


Geology and Mineralogy

This document consists of 50 pages. Series A。

UNITED STATES DEPARTMENT OF THE INTERIOR

GEOLOGICAL SURVEY

SUMMARY OF THE MINERALOGY OF THE COLORADO PLATEAU URANIUM ORES*

By

Alice D. Weeks, Robert G. Coleman, and Mary E. Thompson

February 1956

Trace Elements Investigations Report 583

This preliminary report is distributed without editarial and technical review for conformity with official standards and nomenclature. It is not for public inspection or quotation.

*This report concerns work done on behalf of the Division of Raw Materials of the U.S. Atomic Energy Commission. 
USGS - TEI- 583

GEOLOCY AND MINERALOCY

Distribution (Series A)

No. of copies

Atomic Energy Commission, Washington ..................

Division of Raw Materials, Albuquerque $\ldots \ldots \ldots \ldots \ldots \ldots \ldots \ldots \ldots$ I

Division of Raw Materials, Austin ................. I

Division of Raw Materials, Butte o................ I

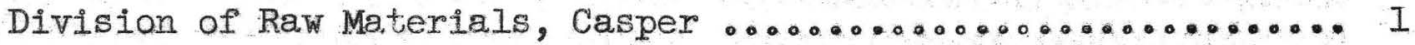

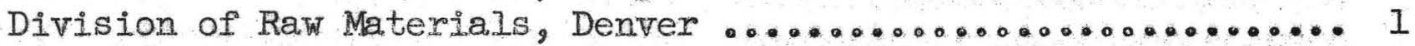

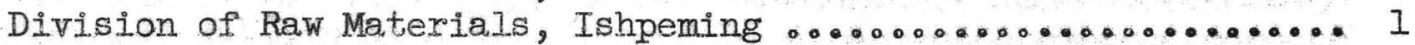

Division of Raw Matexials, Phoenix .............. I

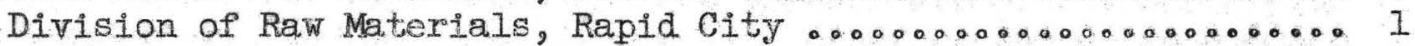

Division of Raw Materials, St. George ono.00000000000000. I

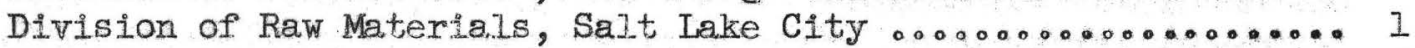

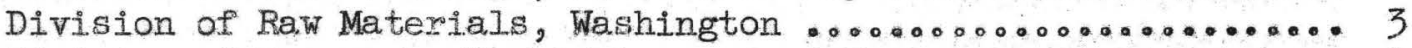

Division of Research, Washington .................. I

Exploration Division, Grand Junction Operations Office ...... 6

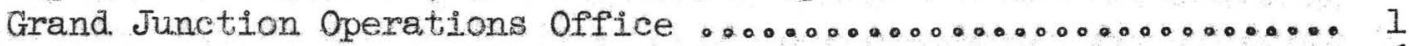

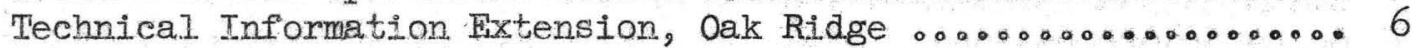

U. S. Geological Survey:

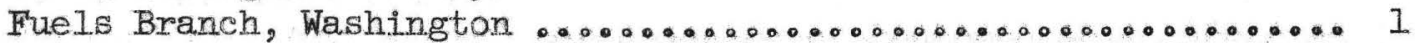

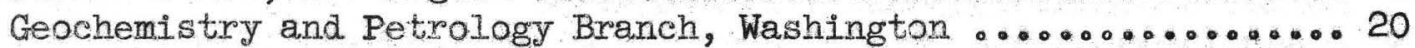

Geophysics Branch, Washington a.....

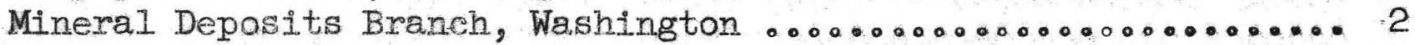

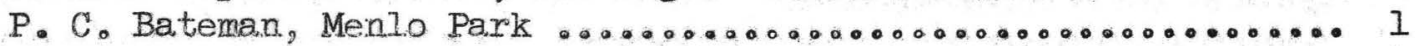

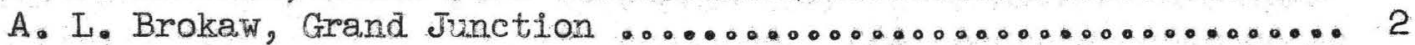

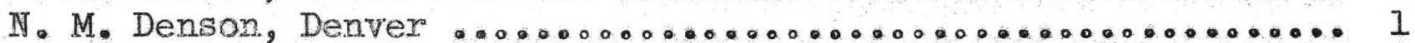

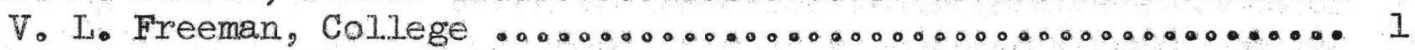

R. I. Griggs, Albuquerque $\ldots \ldots \ldots \ldots \ldots \ldots 00000000 \ldots \ldots \ldots \ldots \ldots \ldots$ I

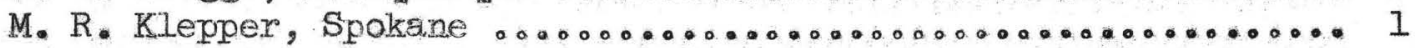

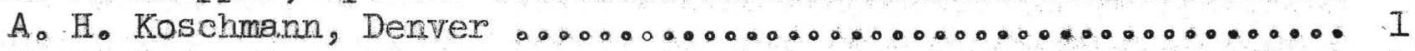

J. D. Love, Laramie $\ldots \ldots \ldots \ldots \ldots \ldots \ldots \ldots \ldots \ldots \ldots \ldots \ldots \ldots \ldots \ldots \ldots \ldots \ldots \ldots \ldots$ I

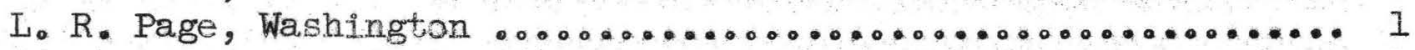

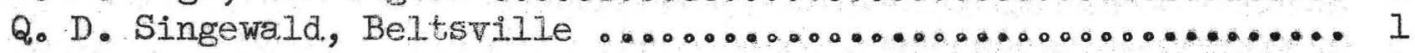

A. E. Weissenborn, Spokane $\ldots \ldots \ldots \ldots \ldots \ldots \ldots \ldots \ldots \ldots \ldots \ldots \ldots \ldots \ldots \ldots$ I

TEPCD, Denver o.......

TEPCO, RPS, Washington, (including master) ............. 2 


\section{CONTENTS}

Page

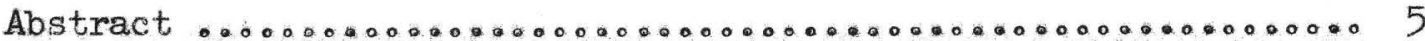

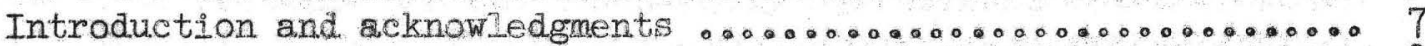

Classification 00000000000000000000000000000000008

Mineralogy of the primary ores (unoxidized) .0.0.00000.0.0.0. 14

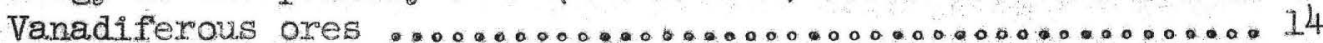

Vanadium-uranium ratio greater than $15: 1$ o0.00000000 14

Vanadium-uranium ratio between $15: 1$ and $1: 1$. o. o. o. 18

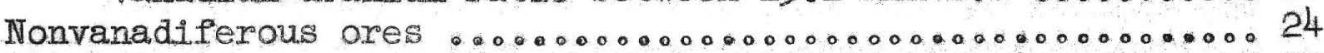

oxidation sequence and mineralogy of vanadiferous uranium ores .. 27

Early stage of oxidation o000000000000000000000000000 27

Corvusite ore, partily oxidized o00000000000000000000000000028

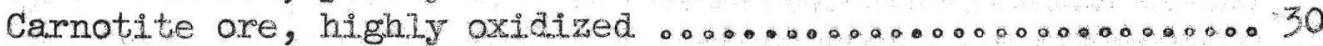

Mineralogy of oxidized nonvanadiferous uranium ores ooo.o.

Uranium minera.Is o.

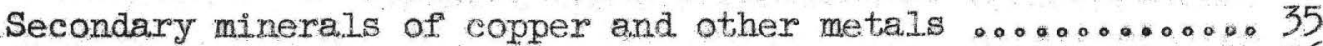

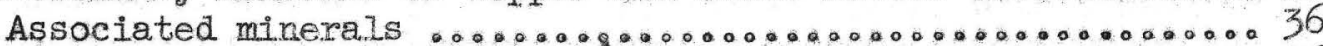

Relation of oxidation to water saturation of ore onon.

Unoxidized ore in wet mines at or close to the water

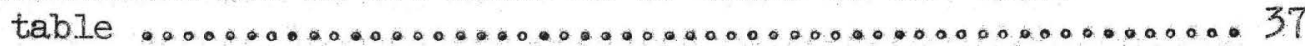

Partly oxidiged deposits, above the main water table but

in protected locations where molsture is held ......... 37

Dry mines with oxidined vanadiferous ore noopopooponopo. 39

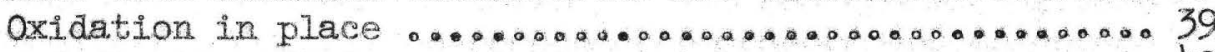

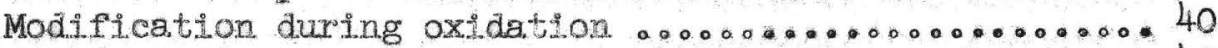

Ore sandstone directly at the surface of mesas o....... 42

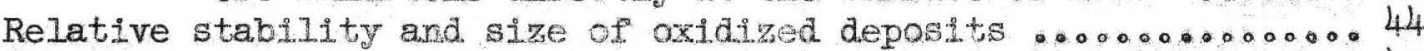

Secondary enrichment 00000000000000000000000000000000000000.45

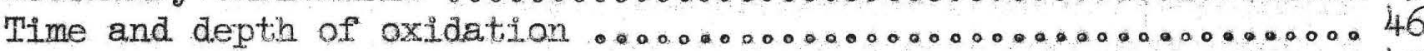

References o0.000000000000000000000000000000000000000047

\section{ILIUSTRATIONS}

Plate 1 A. Primary vanadiferous ore, Fall Creek mine,

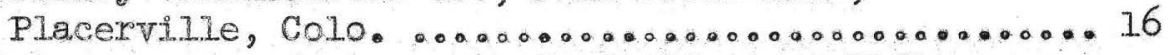

B. Primary vanadiferous ore, Garfield mine, Rifle,

Colo. 000000000000000.000000000000.0. 16

2. A. Primary vanadium-uranium ore, Mi Vida mine, Utah ... 20

B. Pyrite associated with primary ore, Marshbank Canyon. mine, Temple Mountain, Emery County, Utah oooooooo 20 
Plate 3 A. Partly oxidized uranium-vanadium ore, Mi Vida

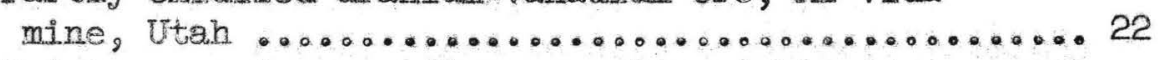
B. Primary uranium vanadium ore, Oversight mine, Montrose County, Colo. ........................22

4 A. Primary uranium.vanadium ore, Mi vida mine, Utah ... 26 B. Primary nonvanadiferous ore, Delta mine, Emery County, Utah 26

\section{TABLES}

Page

Table 1. Uranium minerals found on the Colorado Plateau ....... I0

2. Vanadium minerals found on the Colorado Plateau ...... 12

3. Sulfides, arsenides, selenides, and other accessory metallic minerals found on the Colorado Plateau ..... 15

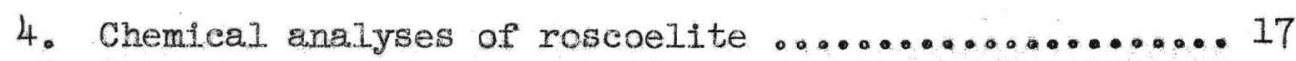

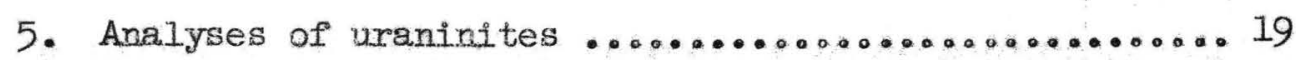


SUMMARY OF THE MINERALOGY OF THE COLORADO PIATEAU URANIUM ORES

By

Alice D. Weeks, Robert G. Coleman, and Mary E. Thompson

ABSTRACT

In the Colorado Plateau uranium has been produced chiefly from very shallow mines in carnotite ores (oxidized vanadiferous uranium ores) until recent deeper mining penetrated black unoxidized ores in water-saturated rocks and extensive exploration has discovered many depasits of low to nonvanadiferous ores. The uranium ores include a wide range from highly vanadiferous to nonvanadiferous and from as much as one percent to a trace of copper, and contain a small amount of iron and traces of lead, zine, molybdenum, cobalt, nickel, silver, manganese, and other metals.

Recent investigation indicates that the carnotite ores have been derived by progressive oxidation of primary (unoxidized) black ores that contain low-valent uranium and vanadium oxfdes and silicates. The uranium minerals, uraninite and coffinite, are associated with coalified wood or other carbonaceous material. The vanadium minera.ls, chiefly montroseite, roscoelite, and ather vanadium silicates, occur in the interstices of the sandstone and in siltstone and clay pellets as well as associated with fossil wood. Calcite, dolomite, barite and minor amounts of sulfides, arsenides, and selenides occur in the unoxidized ore.

Partially oxidized vanadiferous ore is blue black, purplish brown, or greenish black in contrast to the black or dark gray unoxidized ore. Vanadium combines with uranium to form rauvite. The excess vanadium is present 
in corvusite, fernandinite, melanovanadite and many other quadrivalent and quinquevalent vanadium minerals as well as in vanadium silicates. Pyrite and part or all of the calcite are replaced by iron oxides and gypsum.

In oxidized vanadiferous uranium ores the uranium is fixed in the relatively insoluble minerals carnotite and tyuyamunite, and the excess vanadium commonly combines with one or more of the following: calcium, sodium, potassium, magnesium, aluminum, iron, copper, manganese, or barium, or rarely it forms the hydrated pentoxide. The relatively stable vanadium silicates are little affected by oxidation.

The unoxidized nonvanadiferous ores contain uraninite and coffinite in close association with coalified wood and iron and copper sulfides, and traces of many other sulfides, arsenides and selenides. The oxidized. nonvanadiferous ores differ from the vanadiferous ores because, in the absence of vanadium to complex the uranium, a great variety of secondary yellow and greenish-yellow uranyl minerals are formed. The uranyl sulfates and carbonates are more comon than the oxldes, phosphates, arsenates, and silicates, Because the sulfates and carbonates are much less stable than carnotite, the oxidized nonvanadiferous ores occur only as halos around cores of unoxidized ore and do not form large oxidized deposits close to the surface of the ground as carnotite ores.

Oxidation has taken place since the lowering of the water table in the present erosion eyele. Because of local structures and the highly lenticular character of the fluviatile host racks perched water tables and watersaturated lenses of sandstone are common high above the regional water table. Unoxidized ore has been preserved in these water-saturated rocks and the boundary between oxidized and unoxidized ore is very irregular. 


\section{INTRODUCTION AND ACKNOWLEDGMENTS}

Vanadiferous uranium ores were discovered in sandstones in western Colorado in 1898 and carnotite, a yellow secondary uranyl vanadate min.eral, was named the following year (Friedel and Cumenge, 1899). At first the ores were mined chiefly for radium, later for vanadium, and recentiy for uranium (Coffin, 1921; Fischer, 1942; Fischer, 1950). For many years the production was from oxidized ore in shallow mines, and the Plateau ores became characterized as carnotite ores (Hillebrand and Ransome, 1905; Hess, 1933). Recent extensive exploration and deeper mining, in many places in the Plateau, have penetrated black unoxidized vanadiferous ore below perched water tables or close to the main water tabje. Also nonvanadiferous ores, both oxidized and unoxidized, have been found. Much of the present uranium production in the Plateau is from unoxidized or primary ore. The deposits are now generally referred to as sandstone-type uranium deposits rather than carnotite deposits.

The chief uranium producing horizons in the Colorado Plateau are in the Morrison formation of Late Jurassic age and contain vanadiferous uranium ore. Important production also comes from the Shinarump conglomerate and the basal sandstones of the Chinle formation of Late Triassic age. These contain vanadiferous uranium ore in Monument Valley, Arizona; Big Indian Valley, San Juan County, and the Temple Mountain area, Emery County, Utah; copper-uranium ore in the White Canyon and Red Canyon areas of San Juan County, Utah; and uranium ore in other areas of Utah and Arizona. The Todilto limestone of Middle Jurassic age on the northeast and east of the Zuni uplift in New Mexico contains uranium and a little vanadium. The Entrada formation along the eastern margin of the Plateau in Colorado con- 
tains vanadium ore with low uranium content. Both a geographic and stratigraphic variation in metal ratios occurs in the Plateau ores.

Thanks are due many of our colleagues on the Geological Survey who have advised or participated in this study. Chemists, spectrographers, and X-ray crystallographers have done much analytical work, and many field geologists, both of the Geological Survey and Atomic Energy Commisa sion, and mining company employees have aided us in this study. References to the geology and mineralogy of various uranium deposits on the Colorado Plateau by J. W. Gruner, P. F. Kerr, and many others have been compined by Cooper (1953, 1954).

\section{CLASSIFICAIION}

The Plateau uranium ores are classified on the basis of whether or not a significant amount of vanadium is associated with the uranium (Weeks and Thompson, 1954). The presence of vanadium has an important chemical and mineralogic control on the uranium during the oxidation of the ore. Vanadiferous uranium ore ranges in $\mathrm{V}: \mathrm{U}$ ratio from more than $15: 1$ to $1: I$ and contains traces of copper and other metals, but in general the copper content is less than in nonvanadiferous ores. The uranium ores referred to in this report as nonvanadiferous may contain traces of vanadium, and commonly contain minor amounts of copper and other metals, locally as much as 1 percent of copper. The two main types may be subdivided according to the degree of oxidation that has taken place. Mineralogically the types differ greatly because the affinity of vanadium for uranium tends to make the uranyl vanadates, carnotite and tyuyamunite, the chief uranium minerals in oxidized vanadiferous ore, whereas the oxidation of uraninite in nonvanadiferous ore produces a greater variety of secondary yellow and greenish- 
yellow uranyl minerals such as hydrated oxides, carbonates, sulfates, phosphates, arsenates, and silicates (tables 1 and 2). Subdivision of the nonvanadiferous uranium ores on the basis of copper content (Finch, 1954) is unnecessary because the copper is unimportant commercially and. it does not control the uranium during oxidation by complexing as does vanadium. The uranium ore at Temple Mountain in the eastern part of the San Rafael swell in Utah has been referred to as asphaltite ore (Hess, 1922) because of the abundance of asphaltic or other carbonaceous material. However, higher-than caverage carbon content does not prevent classifying this ore on the basis of mineral assemblage with the other vanadiferous uranium ores. All of the Plateau uranium deposits have associated carbona-ceous material and the Temple Mountain ores differ more in degree than kind.

Much more vanadiferou,s than nonvanadiferous uranium ore has been mined. on the Colorado Plateau. This is due to the influence of intensive mioing of vanadium just prior to the recent interest in uranium miningo seven of the nine processing plants on the Plateau in 1955 handled vanadiferous ore and recovered both vanadium and uranium (Ritter, 1955). Recently the production of low vanadiferous and nonvanadiferous ores has increased. The sandstone-type uranium deposits on the south and west flanks of the Black Hills, South Dakota and. Wyoming, are moderately vanadiferous and resemble the carnotite ores of the Colorado Plateau. However, the sandstone-type uranium deposits in the Powder River basin of Wyoming seem to be low vanadiferous and those in the Wind River basin of Wyoming and in Karnes County, Tex., may contain more uranyl phosphates and arsenates than uranyl vanadates. 
Table 1..-Uranium minerals found on the Colorado Plateau.

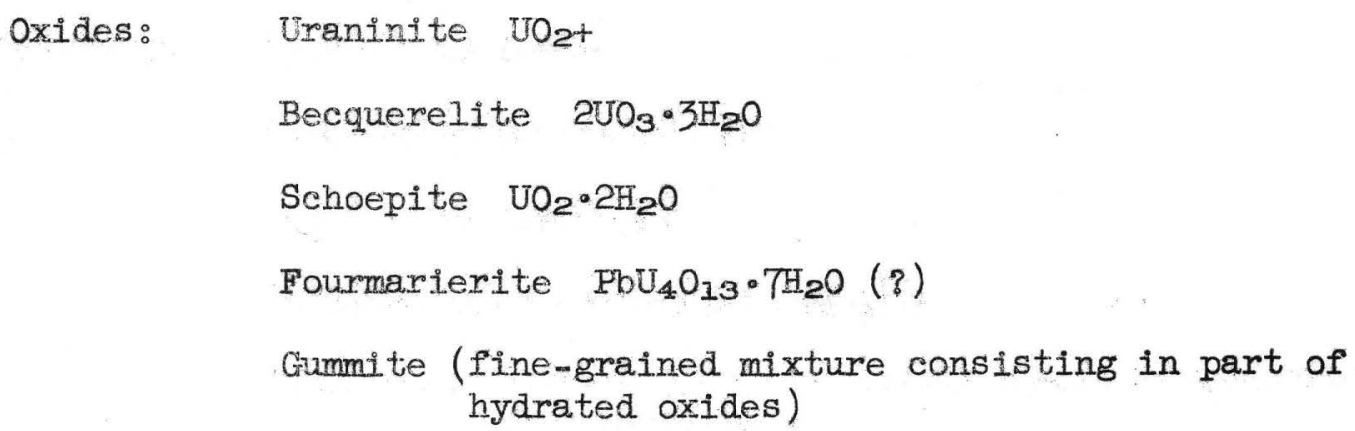


Table 1.- -Uranium minerals found on the Colorado Plateau-Continued.

$$
\begin{aligned}
& \text { Arsenates: Zeunerite } \mathrm{Cu}\left(\mathrm{UO}_{2}\right)_{2}\left(\mathrm{AsO}_{4}\right)_{2} \cdot 10-\mathrm{ILH}_{2} \mathrm{O} \\
& \text { Abernathyite } \mathrm{K}_{2}\left(\mathrm{UO}_{2}\right)_{2}\left(\mathrm{AsO}_{4}\right)_{2} \cdot 8 \mathrm{H}_{2} \mathrm{O} \\
& \text { Metazeunerite } \mathrm{Cu}\left(\mathrm{UO}_{2}\right)_{2}\left(\mathrm{AsO}_{4}\right)_{2} \cdot 8 \mathrm{H}_{2} \mathrm{O} \\
& \text { Novacekite } \mathrm{Mg}\left(\mathrm{UO}_{2}\right)_{2}\left(\mathrm{AsO}_{4}\right)_{2} \cdot 8-\mathrm{IOH}_{2} \mathrm{O} \\
& \text { Silicates: Coffinite } U\left(\mathrm{SiO}_{4}\right)_{1-X}(\mathrm{OH})_{4 X} \\
& \text { Uranophane } \mathrm{Ca}\left(\mathrm{UO}_{2}\right)_{2}\left(\mathrm{SiO}_{3}\right)_{2}(\mathrm{OH})_{2} \cdot 5 \mathrm{H}_{2} \mathrm{O} \\
& \text { Beta-uranophane } \mathrm{Ca}\left(\mathrm{UO}_{2}\right)_{2}\left(\mathrm{SiO}_{3}\right)_{2}(\mathrm{OH})_{2} \cdot 5 \mathrm{H}_{2} \mathrm{O} \\
& \text { Cuprosklodowskite } \mathrm{Cu}\left(\mathrm{UO}_{2}\right)_{2}\left(\mathrm{SiO}_{3}\right)_{2}(\mathrm{OH})_{2} \cdot 5 \mathrm{H}_{2} \mathrm{O} \\
& \text { Sklodowskite } \mathrm{Mg}\left(\mathrm{UO}_{2}\right)_{2}\left(\mathrm{SiO}_{3}\right)_{2}(\mathrm{OH})_{2} \cdot 6 \mathrm{H}_{2} \mathrm{O} \\
& \text { Soddyite }\left(\mathrm{UO}_{2}\right)_{5}\left(\mathrm{SiO}_{4}\right)_{2}(\mathrm{OH})_{2} \cdot 5 \mathrm{H}_{2} \mathrm{O} \\
& \text { Vanadates: Carnotite } \mathrm{K}_{2}\left(\mathrm{UO}_{2}\right)_{2}\left(\mathrm{VO}_{4}\right)_{2} \cdot 1-3 \mathrm{H}_{2} \mathrm{O} \\
& \text { Tyuyamunite } \mathrm{Ca}\left(\mathrm{UO}_{2}\right)\left(\mathrm{VO}_{4}\right)_{2} \cdot 5-\frac{\mathrm{O}_{2}}{\mathrm{H}_{2} \mathrm{O}} \\
& \text { Metatylyamunite } \mathrm{Ca}\left(\mathrm{UO}_{2}\right)_{2}\left(\mathrm{VO}_{4}\right)_{2} \cdot 3-5 \mathrm{H}_{2} \mathrm{O} \\
& \text { Rauvite } \mathrm{CaO} \cdot 2 \mathrm{UO}_{3} \cdot 5 \mathrm{~V}_{2} \mathrm{O}_{5} \cdot 16 \mathrm{H}_{2} \mathrm{O} \\
& \text { Uvanite } 2 \mathrm{UO}_{3} \cdot 3 \mathrm{~V}_{2} \mathrm{O}_{5} \cdot 15 \mathrm{H}_{2} \mathrm{O}
\end{aligned}
$$

Unknowns: Several sulfates, phosphates, and silicates 
Table 2.--Vanadium minerals found on the Colorado Plateau.

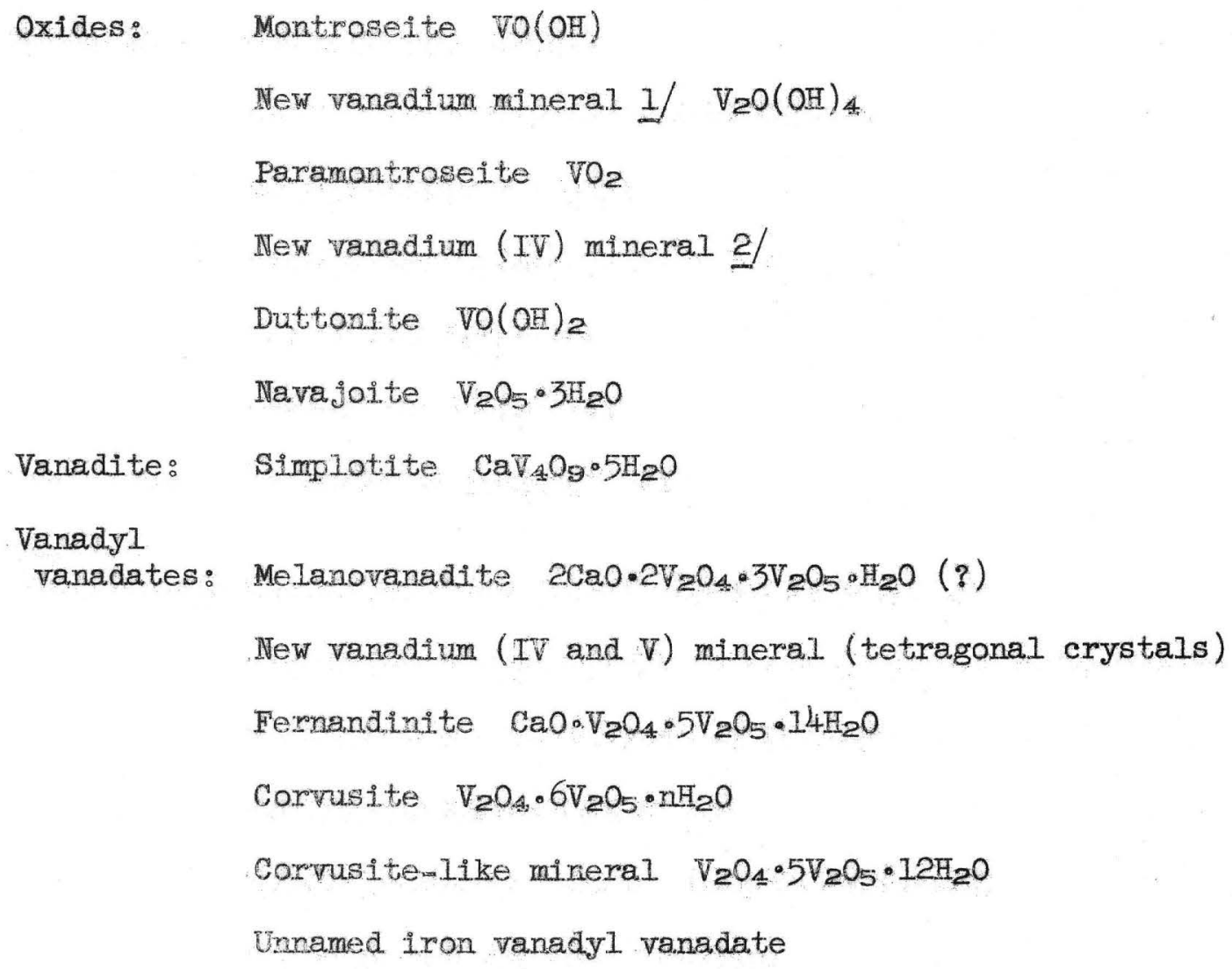


Table 2.-Vanadum minerals found on the Colorado Plateau-Continued.

Vanadates: Pascoite $\mathrm{Ca}_{3} \mathrm{~F}_{20} \mathrm{O}_{28} \cdot 16 \mathrm{H} 2 \mathrm{O}$

Hummerite $\quad \mathrm{K}_{2} \mathrm{Mg} \mathrm{V}_{10} \mathrm{O}_{28^{\circ}} 16 \mathrm{H}_{2} \mathrm{O}$

Uvante $2 \mathrm{UO}_{3} \cdot 3 \mathrm{~V}_{2} \mathrm{O}_{5} \cdot 15 \mathrm{H}_{2} \mathrm{O}$ (?)

Raurite $\mathrm{CaO} \cdot 2 \mathrm{UO}_{2} \cdot 6 \mathrm{~V}_{2} \mathrm{O}_{5} \cdot 2 \mathrm{OH}_{2} \mathrm{O}($ (3)

Hewettite $\mathrm{CaV}_{6} \mathrm{O}_{36} \cdot 9 \mathrm{H}_{2} \mathrm{O}$

Metahewettite 3/ $\mathrm{CaV}_{6} \mathrm{O}_{16} \cdot 3 \mathrm{H}_{2} \mathrm{O}$

Barnes:te $\mathrm{Na}_{2} \mathrm{VVO}_{6} \mathrm{O}_{2} \cdot 3 \mathrm{H}_{2} \mathrm{O}$

Silicates: Roscoelite $\mathrm{K}(\mathrm{Al}, \mathrm{V})_{2}\left(\mathrm{AI}, \mathrm{SI}_{3}\right)_{\mathrm{O}_{10}}(\mathrm{OH}, \mathrm{F})_{2}$

Vanadium-bearing hydrous mica

Vanadium-bearing chlorite

1) Personal communication, H. T. Evens.

2) Personal commonication, T. W. Stern.

3/ Barnes, W. E., 1955, Hewettite and metahewettite: Am. Mineralogist, v. $40, \mathrm{p}, 689.691$. 
MINERALOGY OF THE PRIMARY ORES (UNOXIDIZED)

\section{Vanadiferous ores}

The primary vanadium-uranium ores are characterized in general by their black color and by the presence of low-valent uranium and vanadium oxides and silicates, and copper, iron, lead, and zine sulfides, arsenides, and selenides (table 3 ). These ores should not be confused with the blueblack or corvusite ores which represent an intermediate stage of oxidation. The ores have a wide range of vanadium content and for convenience in description they have been divided into groups on the basis of their vanadium-uranium ratios.

Vanadium-uranium ratio greater than $15: 1$

Vanadiferous ores with low uranium content are charactexized by the dominance of vanadium silicates over vanadium oxides and by the general lack of fossil wood. The unoxidized ores in the Entrada sandstone (Jurassic) of the Rifle and Placerville districts in western Colorado are representative of this group and appear to have a monotonous and simple mineralogy (pl. I). At Placerville roscoelite (table 4 ) is the dominant vanadium mineral occupying the intergranular areas as fine-grained micaceous aggregates, and at Rifle it is accompanied by some vanadium-bearing chlorite and mixed layer mica-montmorillonite (or so-called hydrous mica). No vanadium hydrous mica is present in the primary roscoelite ore at Placerville. In roscoeliterich thin layers either concordant with or cutting across bedding planes the quartz is strongly corroded and microstylolites (Fischer, 1942, p. 380) develop where the quartz grains are in juxtaposition. Montroseite (Weeks, Cisney, and Sherwood, 1953) is interleaved with the roscoelite aggregates 
Table 3.--Sulfides, arsenides, selenides, and other accessory metallic minerals found on the Colorado Plateau.

Elements: Native arsenic

Native selenium

Sulfides: Pyrite Fes?

Cobaltian pyrite ( $\mathrm{Fe}, \mathrm{Co}) \mathrm{S}_{2}$ (as much as 1 percent Co)

Selenian pyrite $\mathrm{Fe}(\mathrm{S}, \mathrm{Se})_{2}$ (as much as 5 percent $\mathrm{Se}$ )

Marcasite $\mathrm{FeS}_{2}$

Selenian marcasite $\mathrm{Fe}(\mathrm{S}, \mathrm{Se})_{2}$ (as much as I percent $\mathrm{Se}$ )

Galena $\mathrm{PbS}$

Spha,lerite ZnS

Chalcocite Cu.2S

Digenite $u_{z-x^{S}}$

Bornite $\mathrm{Cu}_{5} \mathrm{FeS}_{4}$

Cha.leopyrite CuFeS $_{2}$

Greenock:ite cds

Covelinte cus

Molyodenite $\mathrm{MoS}_{2}$

Jordisite I/ Mo sulfide (?)

Rea.lgar AsS

Tennantite (Cu, $\left.\mathrm{F}^{2}\right)_{12} \mathrm{As}_{4} \mathrm{~S}_{13}$

Arsenides: Domeykite $\mathrm{Cu}_{3} \mathrm{As}$

Selenides: Clausthalite PbSe

Eucairite CuAgse

I) Gruner and Gardiner (1952). 


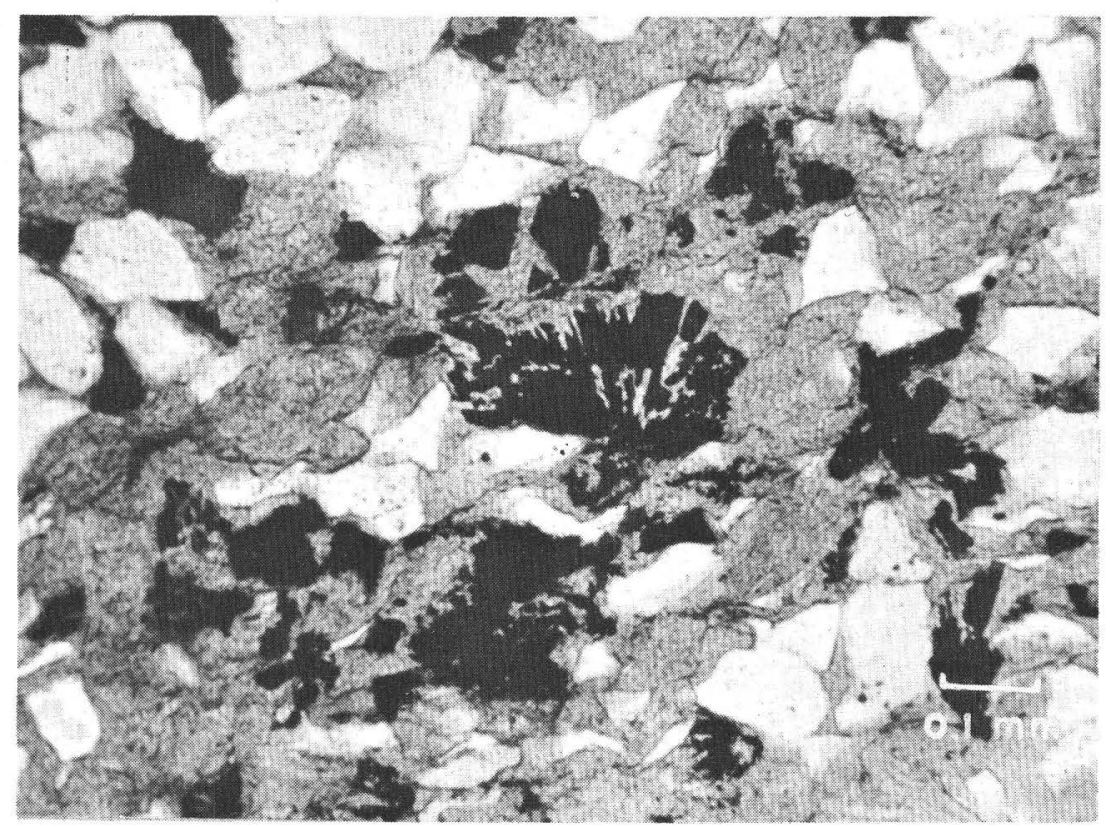

A. Primary vanadiferous ore 1700 feet in from the portal, Fall Creek mine, Placerville, Colorado. The irregular white areas are strongly corroded quartz sand grains. The gray groundmass is roscoelite and the black opaque areas are montroseite, some showing radiating, bladed crystals. Thin section.

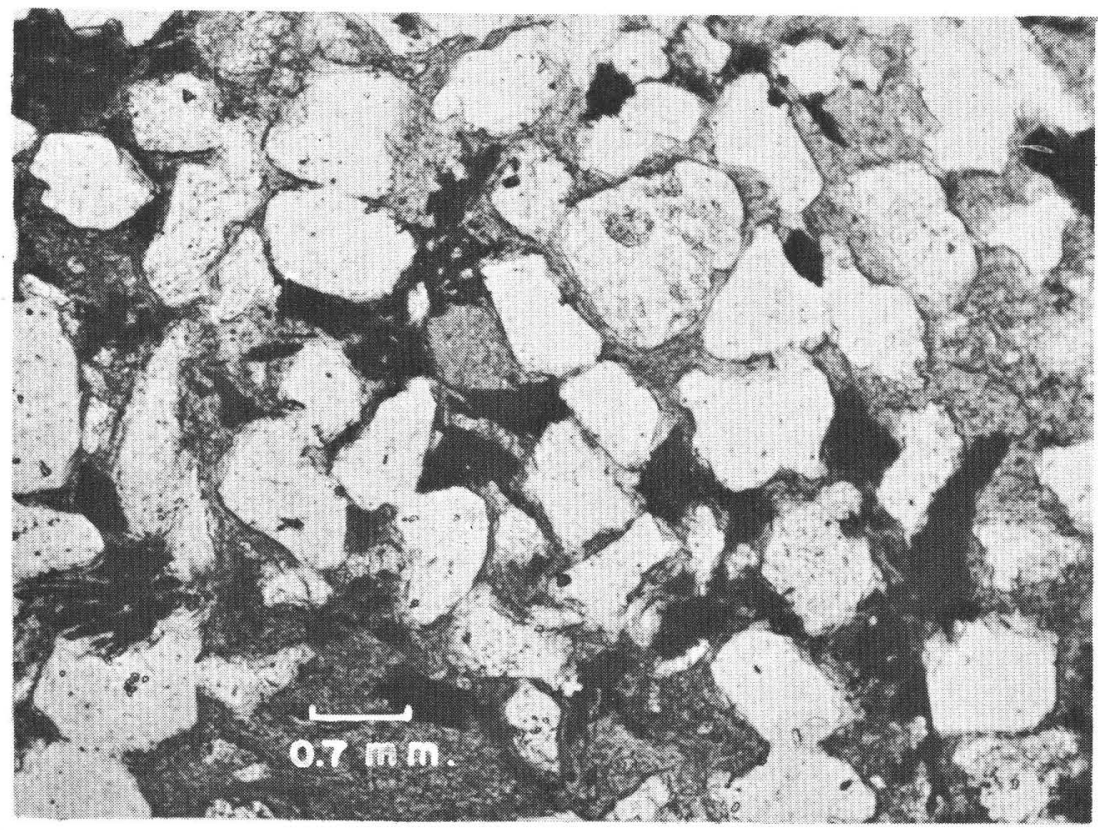

B. Primary vanadiferous ore 7000 feet in from the portal, Garfield mine, Rifle, Colorado. The irregular white areas are quartz grains showing some corrosion. The gray intergranular areas are roscoelite and the black opaque grains are montroseite. Thin section. 
Table 4.m-Chemical analyses of roscoelite.

1. 2

Metal atoms

\begin{tabular}{|c|c|c|c|c|c|}
\hline $\mathrm{SiO}_{2}$ & 44.81 & 40.40 & 3.045 & \multirow{4}{*}{$\begin{array}{l}0.944 \\
0.682\end{array}$} & \multirow{2}{*}{4.000} \\
\hline $\mathrm{TiO}_{2}$ & 0.56 & 0.20 & 0.011 & & \\
\hline $\mathrm{A}_{1} \mathrm{O}_{3}$ & 18.42 & 18.31 & 1.626 & & \\
\hline $\mathrm{V}_{2} \mathrm{O}_{3}$ & 20.41 & 17.57 & 1.061 & & \\
\hline $\mathrm{V}_{2} \mathrm{O}_{4}$ & $\mathbb{N}_{0} \mathrm{D}_{0} *$ & 1.69 & 0.092 & & 1.967 \\
\hline Feo & 1.58 & 0.61 & 0.039 & & \\
\hline MgO & 0.83 & 0.83 & 0.093 & & \\
\hline $\mathrm{K}_{2} \mathrm{O}$ & 8.28 & 11.26 & 1.081 & & 1.081 \\
\hline $\mathrm{Na}_{2} \mathrm{O}$ & 0.07 & $\mathbb{N} \cdot D_{0} *$ & & & \\
\hline $\mathrm{H}_{2} \mathrm{O}+$ & 3.87 & 3.54 & & & \\
\hline $\mathrm{H}_{2} \mathrm{O}$. & 0.53 & 0.40 & & & \\
\hline $\mathrm{CaO}$ & 0.20 & 3.10 & Clogerta & smonertu & \\
\hline $\mathrm{CO}_{2}$ & $N_{0} \cdot D_{*} *$ & 2.42 & 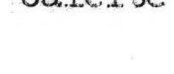 & 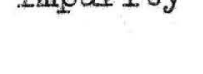 & \\
\hline $\mathrm{Cr}_{2} \mathrm{O}_{3}$ & 0.02 & $N_{0} D_{0} *$ & & & \\
\hline Mno & 0.01 & $\mathbb{N}_{0} D_{*} *$ & & & \\
\hline $\mathrm{LiO}_{2}$ & none & $N \cdot D_{0} *$ & & & \\
\hline $\mathrm{F}$ & 0.15 & less than 0.10 & & & \\
\hline $\mathrm{P}_{2} \mathrm{O}_{5}$ & 0.01 & $N \cdot D_{0} *$ & & & \\
\hline & 99.75 & 100.33 & & & \\
\hline Less $0=F$ & 0.06 & & & & \\
\hline & $\overline{99.69}$ & & & & \\
\hline
\end{tabular}

1. Roscoelite from Placerville, Colorado (Fischer, Haff, and Rominger, 1947, p. 124)。Analyst, V. North.

2. Roscoelite from Fall Creek mine, Placerville, Colorado, collected by A. L. Bush. Analyst, H. Levine.

* NoD., not determined. 
as small discrete crystaline rosettes. Paramontroseite (Evans and Mrose, 1955) may local1y supersede montroselte where oxidation has commenced. Calcite or dolomite commonly accompanies the montroselte and roscoelite and appears to be contemporaneous with the vanadium mineralization. Minor but persistent galena (with clausthalite in solid solution) and chalcopyrite are accompanied by sparse pyrite and marcasite. Small amounts of uranium are present, but its minera.logic occurrence has not been determined completely.

Vanadiumuranium ratio between $15: 1$ and $1: 1$

Ores with vanadium-uranium ratios ranging between $15: 1$ and 1:I accur extensively in the Salt Wash sandstone member of the Morrison formation (Iate Jurassic) and to a lesser extent in the Shinarump conglomerate and. Chinle formation (Itriassic) and in other formationso

The uranium oceurs in uraninite (table 5) and coffinite (Stieff, stern, and Sherwood, 2955) in the primary ore and almost wh thout exception is associated with coallified wood or other carbonaceous material. Vartous stages of uranium saturation of the coalified wood have been abserred. An ordinary $\mathrm{X}$-ray diffraction powder photograph may not detect uraninite or coffinite unless several percent uranium is present.

Uraninite preferentially replaces the cell walls of the wood structure (pl. 2A). Commonly the cell lumens (cavities) are filled by sulfides (pl. $2 B$ ), but if the lumens are vacant the uraninite also forms in this area. Where the original wood structure was collapsed or vitrainized or both during diagenesis, the uraninite intimately impregnates or replaces the coal and faithfully retains the coaly struetures. Uraninite deposited in the sandstone bordering fossil wood may show replacement of earlier sulfides, 
Table 5.-Analyses of uraninites o1.2/

1

$\mathrm{UO}_{3}$

$\mathrm{UO}_{2}$

$\mathrm{ThO}_{2}$

$\mathrm{PbO}$

Cuo

$\mathrm{Ni}_{2} \mathrm{O}_{3}$

$\mathrm{CO}_{2} \mathrm{O}_{3}$

$\mathrm{Fe}_{2} \mathrm{O}_{3}$

$\mathrm{TiO}_{2}$

$\mathrm{Al}_{2} \mathrm{O}_{3}$

$\mathrm{Zno}$

Mno

$\mathrm{SiO}_{2}$

CaO

$\mathrm{Ba} . \mathrm{O}$

SrO

$\mathrm{H}_{2} \mathrm{O}+$

$\mathrm{H}_{2} \mathrm{O}$ -

$\mathrm{V}_{2} \mathrm{O}_{5}$

$\mathrm{s}$

As

$\mathrm{Se}$

F

0 for $F$

Total

Specific gravity

Unit cel1
31.08

52.28

nis

$0.7^{4}$

2.96

N.D.*

M.D.*

2. 21

$\mathrm{NO}_{0} \mathrm{D}^{*}$

0.30

$\mathrm{No}_{\mathrm{a}} \mathrm{D}_{\mathrm{o}} *$

$N_{0} D_{0} *$

2.87

2.22

0.15

0.99

0.28

0.54

1.70

0.025

nili

0.21

97.54

0.11.

97.43

9.2

$a_{0}=5.43$
20.58

42.49

$\mathrm{N} . \mathrm{D} . *$

1.48

$\mathrm{N} . \mathrm{D}_{0}$ *

0.40

0.64

2.93

0,29

1. 28

4.09

0.22 ?

4.35

2.40

5.27

0.34

. 2.2 .27

0.70

0.22

4.35

0.013

0.003

0.28

92.34

0.12

92.22

8.6

$a_{0}=5.43$

I/ Analyst: GIen Edgington, U。 So Ceologleal Survey。

2) Age determinations on these uraninites have been published by Stieff and Stern (1952).

* N.D., not determined.

1. Happy Jack mine, White Canyon, Utah. Probably contains guartz, Pyrite, chalcoeite, and chalcopyrite as minor impurities.

2. Shinarump No. 1 mine, Seven Mile Canyon, Grand County, vtah. Probably contains pyrite, quartz, calcite, and barite as minor impurities. 


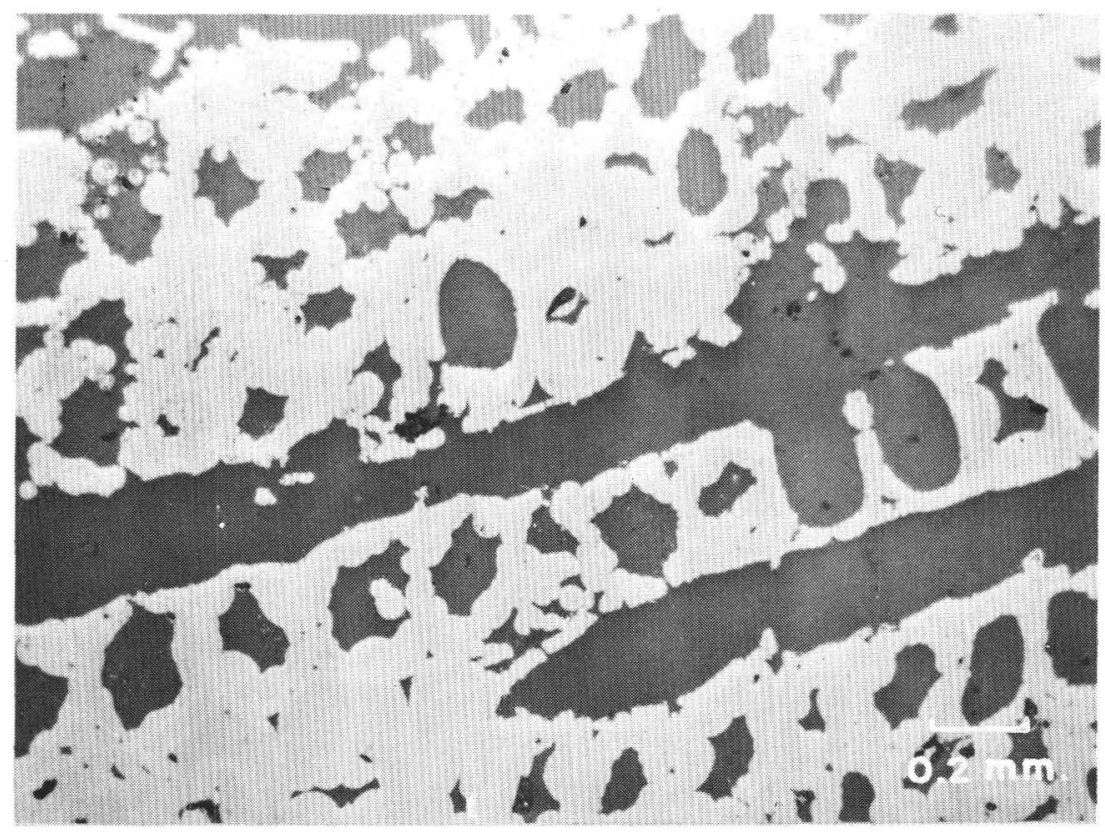

A. Primary vanadium-uranium ore, Mi Vida mine, San Juan County, Utah. Uraninite (light gray) replaced cell walls of coalified wood and partially infilled the lumens. Calcite (dark gray) filled the remainder of the lumens and fractures along the wood rays. Polished section.

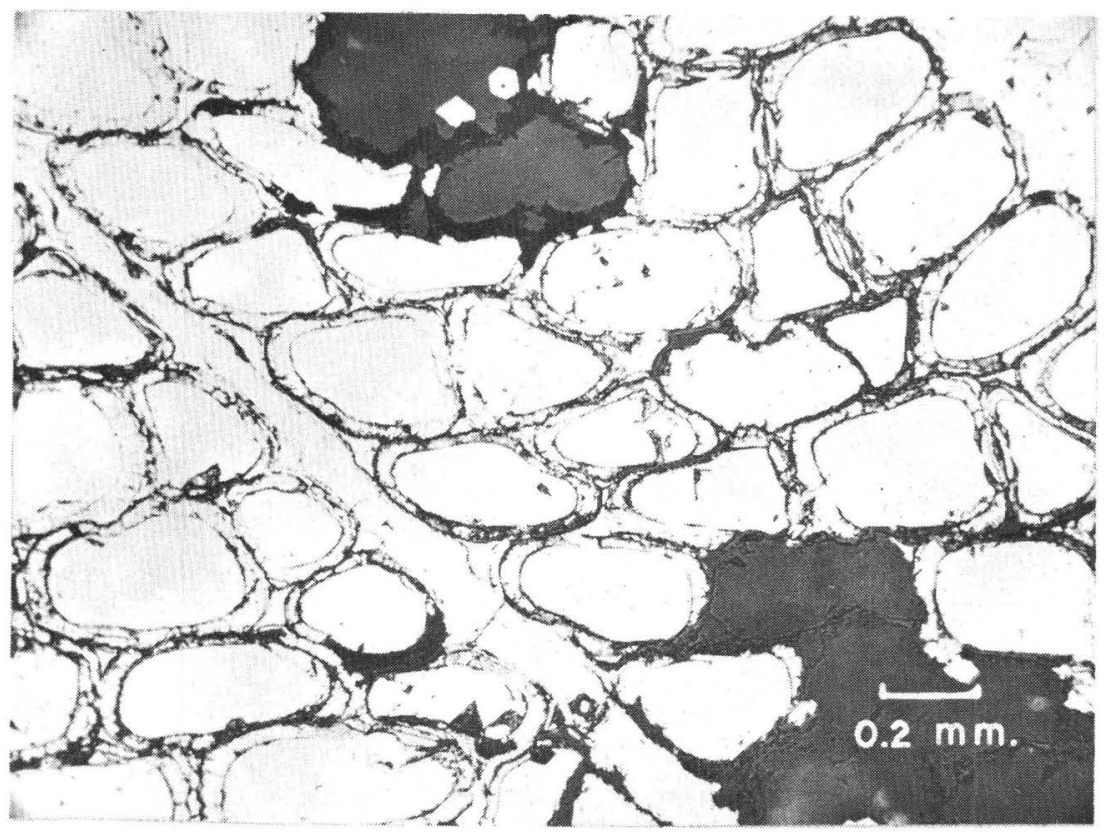

B. Pyrite associated with primary ore, Marshbank Canyon mine, Temple Mountain, Emery County, Utah. Pyrite (white) replaced the cell walls of coalified wood and impregnated the lumens. The dark particles are quartz. Polished section. 
or detrital quartz, or be intimately intergrown with calcite or dolomite. Coffinite is always found within coalified wood where it fills the cell cavities. Most of the occurrences of coffinite are in vanadiferous ores, and many of these are in the Salt. Wash sandstone member of the Morrison formation in the Uravan mineral belt of western Colorado (Fischer and Hilpert, 1952).

Detailed study of polished sections of mineralized carbonaceous material indicates that much of the so-ealled asphaltite ore is sasdstone containing many small detrital fragments of coalified wood with some interstitial insoluble carbonaceous matter that is anistropic and does not show any cell structure. The quartz grains in the impregnated sandstone bordering the wood are commonly corroded. Particularly in the Temple Mountain area this type of ore is further impregnated or coated along joint surfaces with thick brown crude oil. The chemical character of these carbonaceous materials is discussed by Breger and Deul (1955).

In the primary ores of this group vanadium oxides appear to be more abundant locally than vanadium s2licates, The chief primary oxide, montw roseite $\mathrm{VO}(\mathrm{OH})$, is easily oxidized to the more commonly observed paramountroseite. Another primary vanadium oxide $\mathrm{V}_{2} \mathrm{O}(\mathrm{OH})_{4}$ has recently been identified from South Dakota and New Mexico (personal communication, H. T. Evans, J. W. Adams, and $A_{0}$ G. KIng). In places montroseite impregnates the fossil wood by filling cell cavities, but the growth of its elongate crystals soon obscures the wood structure. Typically its strong crystallinity causes the formation of rosettes and bands of intricate and sinuous nature either in contraction fractures in fossil wood (pl. 3) or in interstitial areas of the sandstone (Weeks, Cisney, and Sherwood, 1953, p。 1237). 


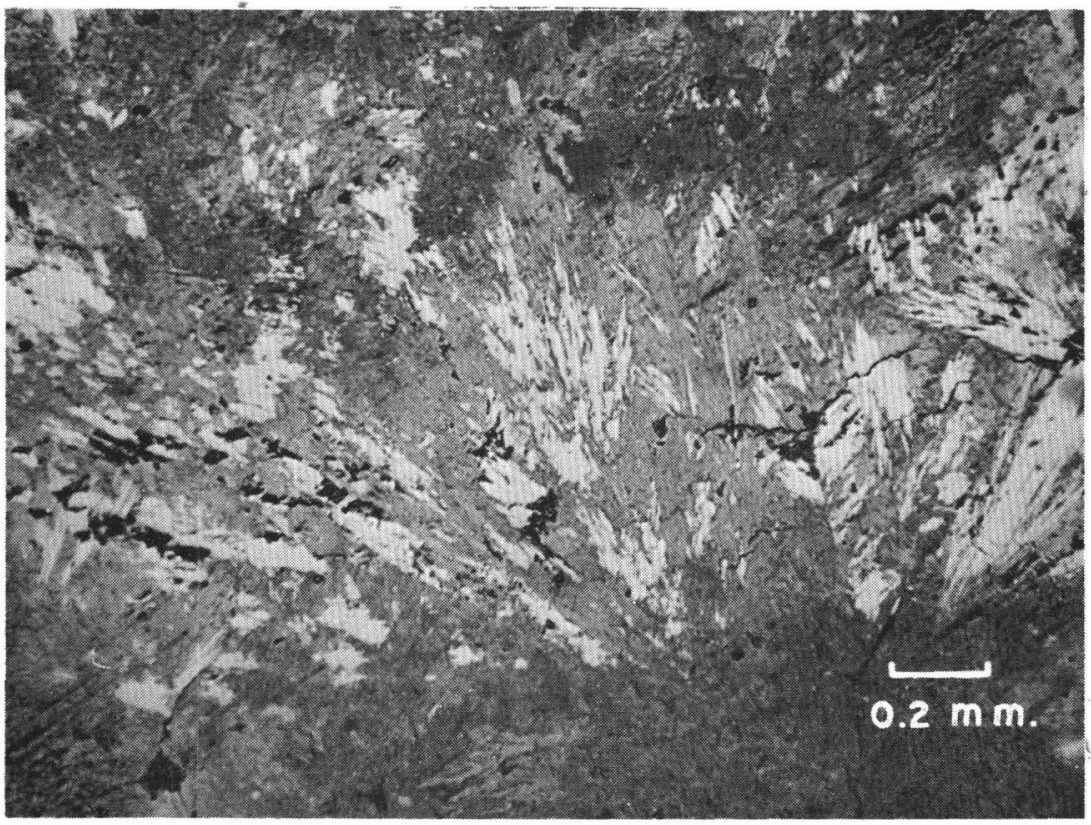

A. Partly oxidized uranium-vanadium ore, Mi Vida mine, San Juan County, Utah. Light-colored needlelike paramontroseite crystals replaced by dark-gray, massive new vanadium (IV) mineral. Polished section.

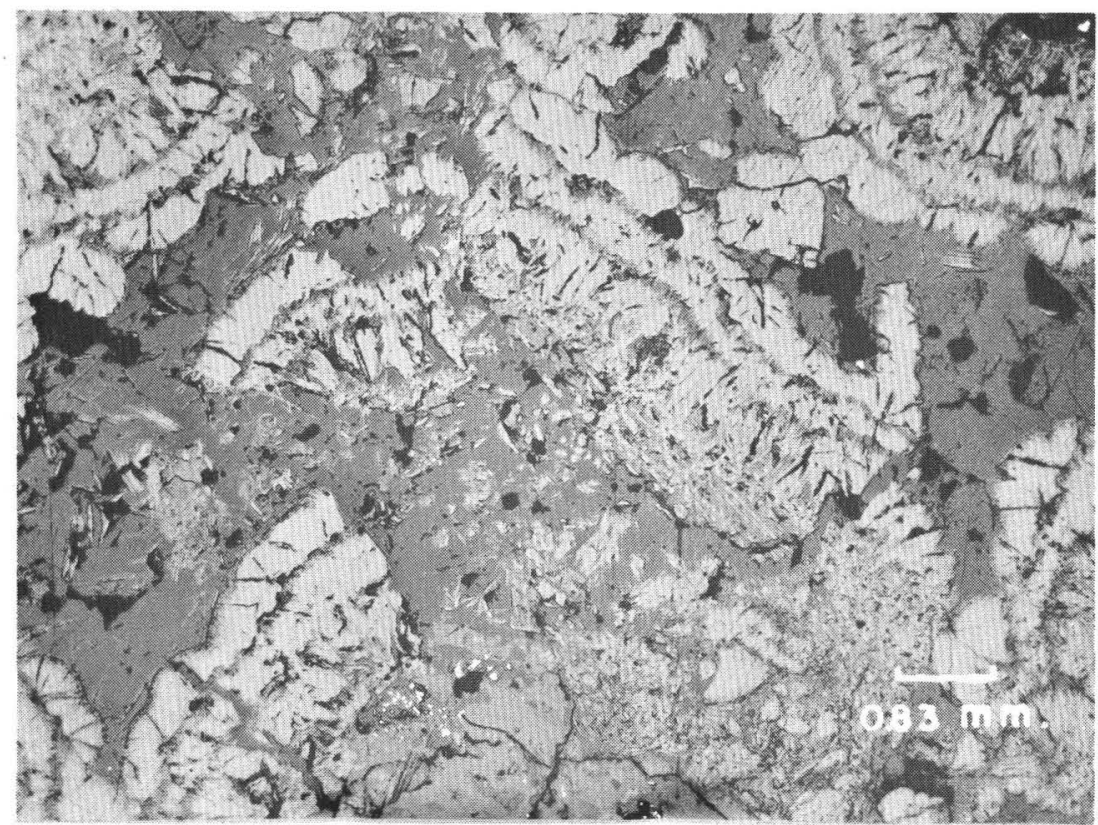

B. Primary uranium-vanadium ore, Oversight mine, Montrose County, Colorado. Banded aggregates of montroseite fractured and healed later by calcite (dark gray). The medium gray patch along the bottom is coalified wood. Polished section. 
Associated with the montroselte and paramontroseite in the inter. granular matrix are vanadium silicate minerals. Vanadium-bearing vhlorite may be one of the most important vanadium silicates in the primary ores. Intensive study of a smal1 number of samples (Hathaway, 1955) indicates that roscoelite is not an important mineral in this group, but that vana dium hydromica, characterized as a mixed layer mica-montmorilionite clay, is commonly present and may contain considerable amounts of vanadium. The vanadium silicates impart a deep greevish or brownish color to the rock and in thin section show a moderate birefringence and a marked pleochroism. A small amount of kaolinite may also be present but does not contain substi.u tuted vanadium.

Pyrite and marcasite are the most common sulfides associated with the primary ores and two distinct generations of iron sulfides have beex recognized. Sulfides formed during diagenesis impregnate or form pseudomorphs of wood or occur as nodules and are considered prenre. Euhedral and massive pyrite associated with uraninite and galena are considered penecontemporaneous with the mineralization (pI, 4A), Detailed study of the iron sulfides shows that those associated with mineralization have been enriched In cobalt and nickel relative to the diagenetic sulfides. Galena is commonly present within the uraninite and as later vein material eutting uraninite, indicating two generations. Chalcopyrite, chalcocite, digenite, sphalerite, molybdenite, greenockite, native arsenic, and realgar occur sparingly in the primary vanadiferous ores.

Calcite and dolomite or either with a smaller amount of barite make up a large part of the gangue. The primary ore from some mines contains less than 6 percent $\mathrm{CaCO}_{3}$, the limit allowed in the mill processing of low-lime ores, but some primary ore contains much more ealeite. At Mi Vida mine, 
San Juan County, Utah, coarsely crystalline, white calcite is intimately associated with both montroseite and uraninite and fills spaces originally occupied by flattened branches and twigs of fossil wood. Small remnants of coalified wood as well as the shape of the calcite masses indicate that wood was replaced by calcite. The outer border of the calcite mass i.s commonly penetrated by montroseite needies forming a thin black sheli. Gross (1955, pa 3I) estimates that the calcite content of Mi Vida ore averages 16 percent or bigher and that the calcite content of the host rock (Chinle formation) averages between 22 and 28 percent. Samples of barren Salt Wash sandstone from drill core at depths of several hundred feet have a wide range of calcite content (personal communfcation, N. Archbold, I955). Locally the sandstone host rock is cemented with pre-ore gypsum as in the Jo Dandy area on the faulted margin of the Paradox salt anticline, Montrose County, Colo.

Minor amounts of selenides including clausthalite and eucairite are found in ore within the Salt Wash member of the Morrison formation. Selenian marcasite, pyrite, and chalcocite are also common in the Salt Wash deposits and may contain as much as 5 percent Se substituting for sulfur. Selenium has been detected in ore bodies from other stratigraphic horizons, although primary selenides have not been identified as yet within these deposits.

\section{Monvanadiferous ores}

Deposits in which vanadium is negligible and uranium is the only metal of importance (except where copper may be locally of commercial importance) accur chiefly in the Shinarump conglomerate and basal sandstones in the Chinle formation (Triassic). The ore is found mainly in channels that 
contain carbonaceous material. and mudstone beds; these channels are along the thin edge (pinch-out) of the formation where conglomerate and sandstone beds fill cuts in the underlying formation (Finch, 1955). The Happy Jack mine, San Juan County, and the Hidden Splendor (Delta) mine, Emery County, Utah, are good examples of nonvanadiferous ore.

In general these primary ores are lighter in color than the vanadiferous ores because the black vanadium oxide, montroseite, is lacking, but a few ores with high sulfide content are dark colored. Uranium is contained chiefly in uraninite, and coffinite is scarce or lacking. Coalified wood and diagenetic sulfides are the main controls of uraninite deposition, and the wood is replaced in the same manner as described above.

Abundant sulfides are associated with uraninite in some of these ores (example, Happy Jack mine, Utah), and a more complicated mineralization sequence is evidenced by ambigrous relations between the uraninite and sulfides. Two generations of pyrite have been established in these primary ores with the pyrite in the uraninite showing rims of unidentified nickel and cobalt mineralsm-further evidence of nickel-cobalt enrichment accompany ing the uranium mineralization (p.1. 4B). Copper sulfides, including chalcopyrite, bornite, chalcocite, and covellite are dominant in some mines and lead, zine, and iron sulfides dominate in others. Galena is commonly associated with uraninite either as early euhedral cubes or as late vein material. Sphalerite is very light colored with a low iron content (as at Happy Jack and Delta mines) indicating a temperature of formation below $138^{\circ} \mathrm{C}$ according to the method of KuIlerud (1953). Molybdenum sulfide(?) in trace amount commonly oceurs in mineralized wood. Silver has been noted. in spectrographic analyses of sulfide concentrates, but no silver minerals (other than those previously known at Silver Reef, Washington County, Utah, 


\section{Plate 4}

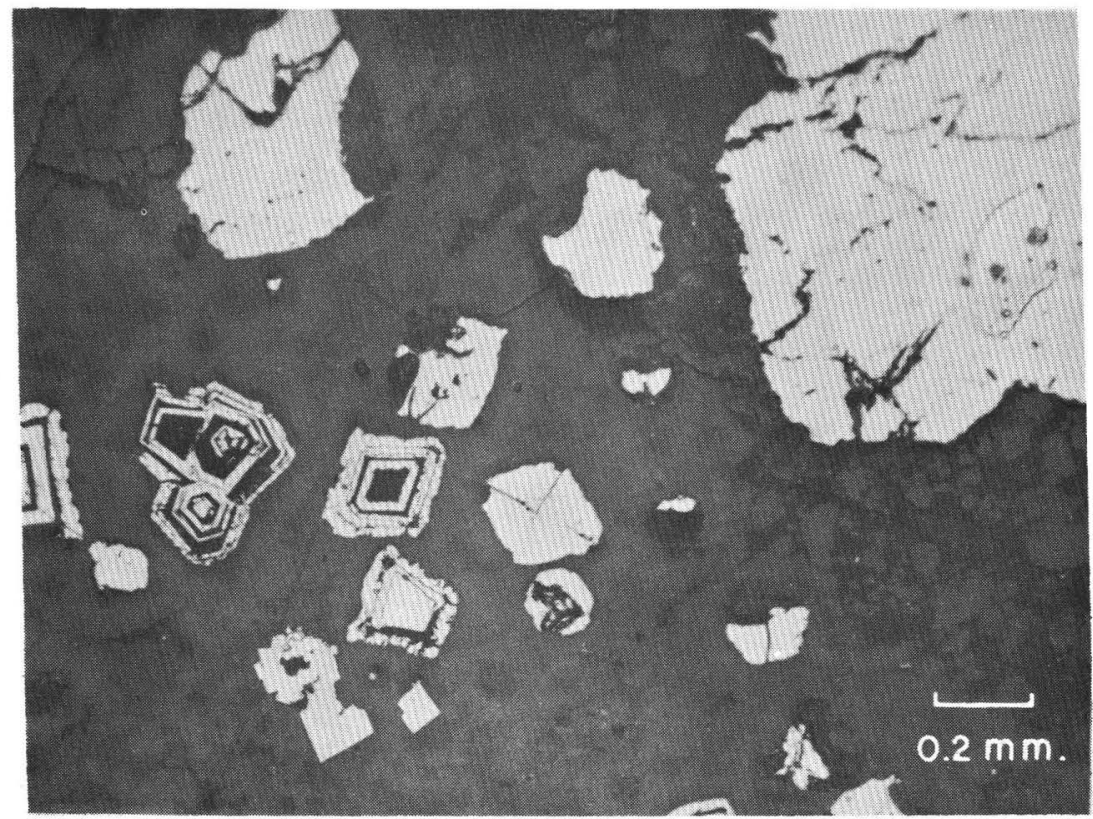

A. Primary uranium-vanadium ore, Mi Vida mine, San Juan County, Utah. The mottled, dark-gray groundmass is an intimate mixture of uraninite and coffinite. Zoned crystals of pyrite show selective replacement by galena, uraninite and coffinite. Two well-developed crystals of galena are in the lower left of the picture. The light irregular patches are also pyrite and they show strong corrosion by the uranium minerals. Polished section.

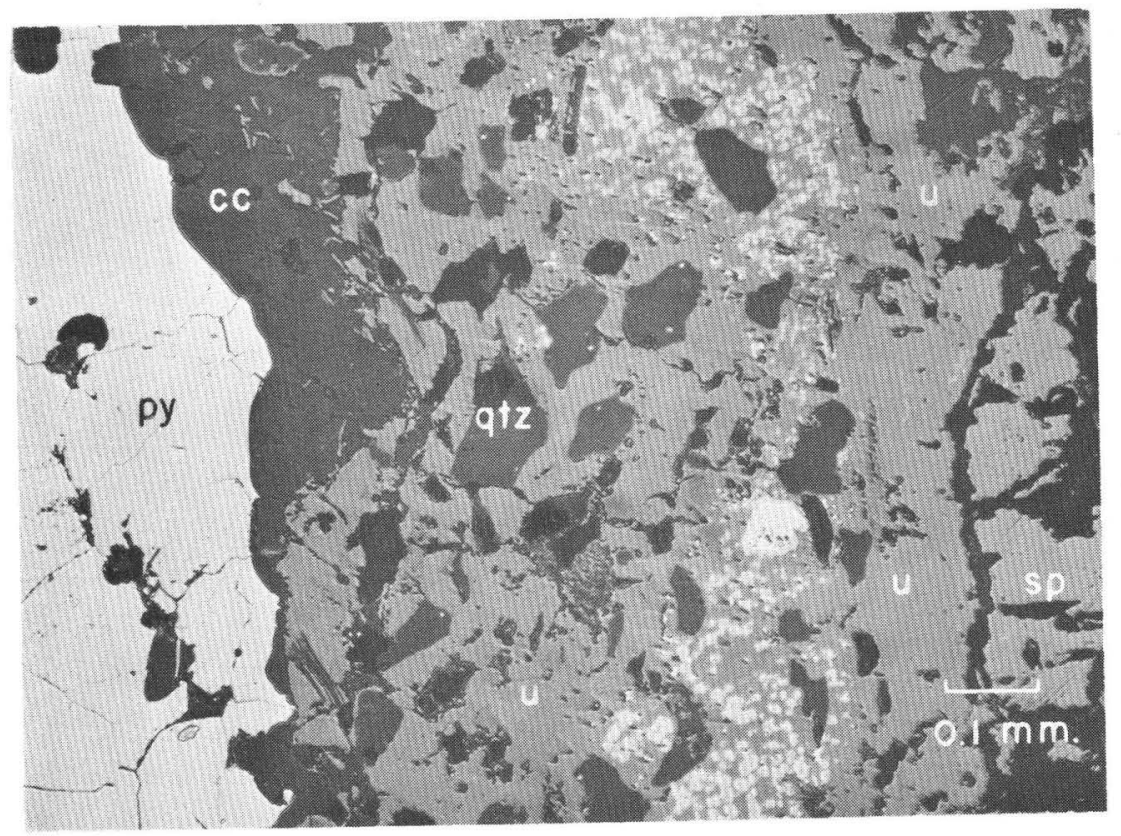

B. Primary nonvanadiferous ore, Delta mine, Emery County, Utah. Detrital quartz (qtz) and massive pyrite (py) replaced by calcite (ce). The light-colored zoned crystals in the uraninite (u) are second generation, cobalt-rich pyrite. A band of sphalerite ( $s p$ ) is along the right hand border of the picture. Polished section. 
and the eucairite at Cougar mine, San Miguel County, Colio.) have been identified. Some uraninite ores have very little accompanying sulfide; these ores are difficult to recognize in the field and must be prospected by careful search with a Geiger or seintillation counter.

Calcite content is high in some mines as at Seven-mile Canyon, near Moab, Utah. Barite is present in small quantity in some nonvanadiferous ore, as at Dirty Devil no. 6 mine, Emery County, Utah, and seems to be less common than in the vanadiferous ores of the Morrison formation.

\section{OXIDATION SEQUEMEE AND MINERAIDGY OF VANADIFEROUS IRANIUM ORES}

\section{Early stage of oxidation}

The primary ores are stable in reducing environments after emplacement and generally retain their original mineral's and textures if they are not exposed to oxidizing conditions. Those ores which have remained below the zone of oxidation, i。e., water takle, retain their primary charaster. In the Colorado Plateau various stages of oxidation may be found auperim imposed on the primary ores because the deposits oreur in many different situations with respect to the water table and also because of variable waterretention capacities of the pore space of the ore sandstones.

The numerous vanadium minerals are very sensitive to changes in oxidation potential and pHo. Most of them have small fields of stability (Garrels, 1953; Garrels and Christ, 1955; and Evans, 1955) and therefore serve as convenient indicators to the degree of oxidation and the $\mathrm{pH}$ of the environment during oxidation. Montroseite, $\mathrm{VO}(\mathrm{OH})$, oxidizes readily to paramontroseite, $\mathrm{VO}_{2}$, (Evans and Mrose, 1955) wher exposed to air, as evidenced by the fact that montroseite specimens in the laboratory commonly alter to 
$\mathrm{VO}_{z}$ in a few montbs' time. Four other new vanadium (IV) minerals, probably all a.lteration products of montroseite, are currentily being studied. by the U. So Geologieal Survey. Three of these occur in several localities and the fourth one, $\mathrm{VO}(\mathrm{OH})_{2}$, is known from only one locality as yet, the Peanut mine, Montrose County, Colo.

Uraninite is altered as uranium (IV) oxidizes to uranium (VI), without producing any megascopically observable change. Coffinite seems to be slightly more resistant to axidation than uraningte. The early oxidation of the primary uranium miners.ls apparently disperses the uranium into black amorphous colloidal phase, an intexmediate step between uraninite and coffinite, and the yellow uranyl minera.ls. No X-ray pattern of any uranium minerals can be obtained from slightly oxidized ore. Considerable oxidation of vanadium takes plare between the time of alteration of uraninite and coffinite and the appearance of uranyl vanadates in corvusite ore. The sulfides are still fresh and unaltered after oxidation of uraninite and montroseite has commenced.

\section{Corvusite ore, partly oxidized.}

Further oxidation of the ores causes a change in color from black to blue black in ores of the corvusite stage. Some greenish-black and brown colors a.lso appear at this stage. As soon as a.l. the vanadium (III) has oxidized to (IV), the vanadium (IV) minerals alter to a group of compounds containing various proportions of vanadium (IV) and (V) with some caleium and iron.

All available urgnium (VI) is combined with vanadium (V) to form the widespread but ill-defined and sometimes inconspicuous mineral rauvite (Hess, 1925) which may be dispersed in mieroseopic grains in massive cor- 
vusite or form glassy or gellike coatings on quartz grains, pebbles, or contraction fractures in mineralized wood. Rauvite ranges in color from purplish black and brownish red in the gellike varieties to orangewred in the powdery aggregates. Its chemical formula is uncertain because samples giving the same X-ray powder pattern have slightly different chemical compositions. The calcium content may not be essential but all rauvite samples have a higher $\mathrm{V}: U$ ratio than carnotite and tyuyamunite. The rare and even-less-well-known mineral uvanite is intermedfate in $\mathrm{V}: \mathrm{U}$ ratio between rauvite and carnotite and was found with raurvite at Temple Mountain, Utah, by Hess (1925).

The best crystallized of the vanadium (IV, V) minerals is melanovanadite, for many years known only from the type locality in Peru and now recognized in a number of mines in the Plateau. Most of the vanadium (IV,V) material, however, i.s poorly crystallized and shows a very complex and intimate mixture of minerals quite similar in appearance and generally referred to in the field as "corvusite." The molecular ratio of vanadium (V) to (IV) ranges from 6 in the corvisite origina.1.1y described. (Henderson and Hess, 1933) to somewhat lower values in other corvusite-like minerals (analyzed by A. M. Sherwood and R. Meyrowitz, 1954). The vanadium (V) to (IV) ratio decreases in this group of minerals as the calcium content increases, with a possible series from corvusite (6) through fernandinite (5) to melanovanadite $\left(1 \frac{1}{2}\right)$, somewhat like the navajoite, hewettite, pascoite, rossite series described below. A new vanadium (IV and $\mathrm{V}$ ) mineral with some iron probably substituted for vanadium occurs in Hummer, North Star, and Peanut mines, a.l. in Montrose County, Colo. It is a dark-red fibrous mineral similar in appearance to hewettite and is being investigated. 
By the time the corvusite stage is reached, some of the associated minerals begin also to show a response to the oxidizing conditions. The sulfides alter to oxides and sulfates, and the selenides alter either directly or indirectly to native selenium. occurrences of native selenium have been described. from South Dakota, Colorado, and Utah (Thompson, Roach, and Braddock, 1956) and many additional occurrences in Wyoming, Utah, New Mexico, and Colorado are known. Depending on the reiative abundance of ealcite with respect to pyrite in the primary ore, a wide range of $\mathrm{pH}$ is possible when the pyrite oxidizes during the corvusite stage and the oxidizing solutions may remain acid or be neutralized by calcite. Part or all of the calcite gangue and cement in the sandstone may be dissolved and the sandstone may be part.ly recemented by gypsum and iron oxides. (The possible addition of calcium carbonate as recent caliche is noted on p. 4.4).

\section{Carnotite ore, highly oxidized.}

As oxidation progresses carnotite and tyuymunite develop chiefly from rauvite, and some may form in other ways (investigation in progress). Once crystallized, the carnotite is remarkably stable and fixes the uranium very effectively. The minerals containing vanadium (IV) and (V) of the corvusite stage oxidize to form vanadium (V) minerals. The specific ores formed depend closely on pH conditions (personal communication, Marvin and Evans), on the presence of certain cations to combine with vanadium, and on several other factors. Vanadium fixes all available uranium in uranyl vanadates, and the excess vanadium may form the hydrated pentoxide, navajoite (Weeks, Thompson, and Sherwood, 1955) or much more commonly it combines with other elements; these include calcium to form hewettite and pascoite (Hillebrand, Merwin, and Wright, 1914), and rossite (Foshag and Hess, 1927), 
potassium and magnes:lum to form hummerithe (Weeks and Thompson, 1954), sodium for sodium vanadate (Weeks and Ihompson, 1954), a.luminum for steigerite (Henderson, 1935), iron for fervanite (Hess and Henderson, 1931), copper for volborthite and calciovolborthite, or barium and copper for vesignieite (Guillemin, 1955). These vanadates range in color from brown through red, orange, yellow, and green to nearly colorless. Hewettite readily dehydrates to metahewettite (Barnes, 1955) and rossite dehydrates to metarossite。

Although the presence of tyuyamite in the "carnotite ores" of the Colorado Plateau has been known for many years (Hilliebrand, 1913, and 1924), the relative abundance of the two minerals is not known quantitatively. Neither is it known how much tyuyamunite has been converted to carnotite (or vice versa) by cation exchange (Hillebrand, 1913, 1924; Mirata, Cisney, Stieff, and Zworykin, 1951). The comon assumption that carnotite is more abundant than tyuymunite in the Uravan mineral belt of Calorado is difficult to evaluate in this mineralogic study, because more identifications have been made of mineral specimens from joint eoatings and mineralized logs than of average ore sandstone with fine-grained uranyl. vanadates disseminated interstitially between the quartz grains and impregnated in clay. Most of the yellow coatings on joints and some of the richly mineralized logs (such as those found in 1950 in the CharleseT No. 2 mine in the Slickrock district, San Miguel County, Colo.) are tyuyamunite, but these account for a small part of the total uranium that has been mined from oxidized ore, and carnotite may be the dominant mineral in the Uravan belt. However, in the Iukachukai group of mines, Apache County, Ariza, and especially in the mines in Todilto limestone in the Grants district, MeKinley and Valencia Counties, N. Mex., tyuyamunite seems to be more abundant than carnotite. The recent 
formation of tyryamunite on joints and fractures is related to the calcium content and alkaline nature of the ground water eaused by the present semiarid climate and to the high calcite content of the country rock. Phoenix (1952) classed most of the ground-water samples from the Salt Wash sandstone member of the Morrison as calcium bicarbonate waters. He found these water samples were a.lkaline as did R. F. Marvin during field wark in 1954 and 1955 (personal communication).

Although in the laboratory tyuymunite is readily base-exchanged to carnotite in the presence of potassium-bearing solutions, evidence i.s lacking that the bulk of Plateau carnotite has undergone exchange. A general rule on the Plateau is that carnotite is typically finer-grained than tyuyamunite although some exceptions to this rule are known. If much of the carnotite had formed by exchange, one would expect the grain size and habit to be similar to that of tyuyamunite. Carnotite apparently occurs where potassium is available in the interstitial hydrous mica of the sandstone, and tyuyamunite forms where calcium is available from the host rock or ground water. Tyuyamunite contains more water than carnotite and when tyuyamunite ores are mined the mineral readily dehydrates to metatyuyamunite (Stern, Stieff, Girhard, and Meyrowitz, in press).

In the oxidized ores of the Uravan belt carnotite, tyuyamunite, and the various brightly colored vanadates are locally abundant but in the bulk of the ore are actually less abundant than the fine-grained, greenish-gray and light-brown vanadium silicates that contributed much of the vanadium mined in the Plateau. (Fischer, 1942) previous to World War II. Mineralogic and chemical study of these vanadium silicates is in progress by Foster, Hathaway, Weeks, and others, and therefore the present description of these minerals is tentative. The outcrop of ore sandstone is commonly gray with 
little or none of the brightly colored minerals. The probable leaching of the vanadates from the outcrop is discussed later. These gray sandstone ores have commonly been termed roscoelite ores in contrast to carnotite ores, but preliminary study suggests that true roscoelite is common only in the Rifle and Placerville districts of Colorado. In the Uravan belt, vanadium-bearing chlorite, and hydrous mica or mixed-layer clays seem to be more abundant than true roscoelite. Some of the vanadium silicate inter. stitial in the sandstone is believed to have persisted practically unchanged from the unoxidized ore, whereas some clay may have become impregnated with vanadium solutions migrating during oxidation.

In areas where the vanadium-uranium ratio is low or the vanadium is moderately low and irregularly distributed, small amounts of other uranium minerals may occur, as uranophane near Grants, N. Mex., and autunite, andersonite, schroeckingerite, and zippeite in the Thompsons district, Grand County, Utah. Study is in progress on the uranium deposits in the Brushy Basin member of the Morrison and in the Todilto limestone of the Grants and Laguna areas in New Mexico which range from low to nonvanadiferous.

\section{MINERALOGY OF OXIDIZE'D NONVANADIFEROUS URANTUM ORES}

\section{Uranium minerals}

The nonvanadiferous uranium ores differ notably from the vanadiferous because oxidation of uraninite in the absence of a significant amount of vanadium produces a greater variety of secondary uranium minerals. These include hydrated oxides, carbonates, sulfates, phosphates, arsenates, and silicates. They are microcrystalline or massive and range in color from orange through yellow, and greenish yellow to green. They fill pore spaces 
or minute fractures in sandstone, conglomerate, or fossil wood and coat joint surfaces and mine walls. Among these minerals none is as predominant as carnotite and tyuyamunite are in the oxidized vanadiferous ore (Weeks and Thompson, 1954). In general these secondary minerals form irregular rims around unoxidized remnants of the primary minerals. They develop next to the core of unoxidized minerals and are removed from the outside of the rim until the source is gone. These secondary uranium minerals generally do not form large deposits of completely oxidized ore as does carnotite, as their relative solubilities are much greater than that of carnotite.

The hydrated uranium oxides are rare and small in quantity because sulfate, carbonate, or some other anion is usually present to combine with uranium. Small amounts of becquerelite, schoepite, and fourmarierite are closely associated with oxidizing uratinite.

In the oxidation of sulfide-rich uraninite ore the most abundant secondary uranium minerals are the uranyl sulfates.ojohannite, uranopilite, zippeite, and other unidentified zippeite-like minerals. These green, yellowishmgreen, and deep-yellow minerals are beautifully developed by evaporation on the wa.1ls of Happy Jack mine in White Canyon, San Juan County, Utah (Trites and Chew, 1955).

The uranyl carbonates are commonly developed wherever the sulfide content of the ore is low and the host rock, or gangue, contains sufficient carbonate, as at Shinarump No. I mine, Utah (Finch, 1954), or where the ground water is carbonate rich. Six uranyl carbonates have been found on the Colorado Plateau, including rutherfordine (rare), liebigite, and schroeckingerite; and three new carbonates, andersonite (Axelrod et al., 1951), bayleyite (Axelrod et al., 1951; Stern and Weeks, 1952), and rabbittite (Thompson, Weeks, and Sherwood, 1955). Small amounts of rutherfordine are found associated directly with 
uraninite. All the uranyl carbonates except rutherfordine form on mine walls and on fracture surfaces by evaporation of uranyl carbonate solutions. Only because of the semiarid climate on the Plateau are these carbonates temporarily preserved. Occasional heavy rains wash away the carbonates, such as bayleyite at Hideout mine and andersonite at Atomic King mine in Utah, and then they gradually accumulate again during a dry season.

The uranyl phosphates are rare in the Plateau because the sandstone host rock is low in phosphate except very locally where fossil bones are preserved. Small amounts of autunite, metacautunite, phosphuranylite (possibly an alteration product of autunite), torbernite, metatorbernite, and bassetite have been found. Small amounts of uranyl arsenates are present: metazeunerite at a number of localities, in White Canyon and in the San Rafael swell, in Utah; and novacekite (Stern and Annell, 1954), abernathyite (Thompson, Ingram, and Gross, 1956), and zeunerite at one locality each. The uranyl silicates, uranophane, sklodowskite, and cuprosklodowskite, are not abundant in the Plateau. The unknown sulfates, phosphates, and silicates that are being studied probably include several new minerals.

\section{Secondary minerals of copper and other metals}

Copper, the chief associated metal in some of the nonvanadiferous ore as well as in some of the vanadiferous deposits, occurs in many secondary minerals, commonly as malachite, azurite, chalcanthite, antlerite, brochantite, and chrysocolla, and rarely as conichalcite, chalcoalumite, and volborthite. Several other metals are present and differ in abundance from one mine to another: iron and manganese in limonite and wad; cobalt in bieberite 
(commonly dehydrated), cobaltocalcite, erythrite, or cobaltoan pickeringite; molybdenum in ilsemannite or ferriomolybdite; and traces of lead, zinc, nickel, and silver (Weeks and Thompson, 1954)。

The presence of brightly colored copper, cobalt, and molybdenum secondary minerals on the rock outcrop or on joint surfaces within a few feet of the cliff face is helpful to the prospector, but many small copper deposits on the Plateau do not contain commercial quantities of uranium.

\section{Associated minerals}

Clay lenses in the ore and mudstone or shale underlying ore are commonly bleached. During oxidation, especially of the sulfide-rich ores, the clays are altered further by development of one or more of the following: kaolinite, jarosite, alunite, or gibbsite. Fluorescent uraniferous opal and allophane coat some joint surfaces and many serve as prospecting guides.

REIATION OF OXIDATION TO WATER SATURATION OF ORE

Second only in importance to the range of primary composition of the Colorado Plateau uranium ores is their range in degree and depth of oxidation. Oxidation depends on access of air to the ore, as in exposed rocks with no soil cover and where evaporation is high, in relatively continuous permeable sandstone beds above the water table, and in strata truncated downdip by a canyon. Oxidation has been prevented or retarded where water is held in the pore space of the ore sandstone, as in strata protected by thick soil cover, in lenticular sandstone beds surrounded by clay, in strata below a perched water table or the main water table, and in strata that dip away from the valley wall. 
Unoxidized ore in wet mines at or close to the water table

A good example of wet unoxidized ore is at the School Section No. 36 mine, T. 30 S., R. 25 E., near the south end of the floor of Lisbon valley, San Juan County, Utah. At a depth of about 70 feet a relatively sharp boundary occurs between partly oxidized ore and wet unoxidized ore containing fossil wood replaced by uraninite and calcite. The mine is at the foot of a long, north-facing slope that rises nearly 2,000 feet to the Monticello Plateau, is covered with vegetation, and hold.s cons.derable moisture.

The Basin No. I mine on the east side of Cottoawond. Creek, west of Blanding, San Juan County, Utah, is wet beeause it is below the level of the creek bed. The mine is in a blanketatype deposit arid the wettest and least oxidized ore is spotted, cemented with ealeite, and contains small coalified wood fragments. Updip, abave the west side of the creek, are many old mines in more oxidized ore.

The unoxidjzed ore at the Peanut mine, Montrose County, Colo., is described by Roach and Thompson, 1955. During mining operations at the Peanut mine, the School Section No. 36, and many other mines in unoxidized ore, considerable water was released from saturated sandstone lenses that contained unoxidized ore.

Partly oxidized deposits, above the main water table but in protected locations where some moisture is held

The Corvusite mine on Beaver Mesa, Grand County, Utah, is a good example of partly oxidized ore with small remnants of unoxidized are. The deposit was mined intermittentIy for more than 40 years and was the type locality for the mineral carvusite (Henderson and Hess, 1933). The mine is located on the updip side of the mesa toward the La Sa,I Mountains, and the 
ore is in richly mineralized fossil trees and relatively small sandstone lenses interbedded. with thick clay so that the ore remains saturated with water. The mesa is more than 7,500 feet above sea level, has considerable soil cover and vegetation, cool temperature, low evaporation, and possibly more rainfall than the lower parts of the Plateau. All of these factors contribute to the continued dampness of the ore and have prevented more than partial oxidation although the mine is high above the main regional water table.

At the Bitter Creek mine on the north side of Paradox valley, Montrose County, Colo., the Salt Wash sandstone member of the Morrison formation dips $15^{\circ}$ to the northeast, away from Paradox valley. These strata are truncated. by the San Miguel River some distance to the north, and water in the mine drains slowly downdip. At Bitter Creek, the ore at the surface of the ground is oxidized, lower than average grade in both vanadium and uranium, and contains gypsum. Mining has progressed several hundred feet downdip through a thick transition zone of partly oxidized ore consisting chiefly of corvusite and rauvite with remnants of unoxidized montroseite or paramontroseite and pyrite. The water-soluble efflorescence, pascoite, forms on the moist corvusite-rich layers. At depth, gypsum and iron oxides are absent and the barren rock is gray rather than buff. Partly oxidized rich ore pockets commonly contain a small amount of radioactive barite. This indicates that recent oxidation of the primary uranium minerals separated trace amounts of radium which, probably as sulfate, formed a coating on the crystals of barite in the gangue. Inasmuch as radium has a half-life of about 1,500 years, the radioactive coating on the barite would lose more than 99 percent of its radioactivity in 15,000 years. Possibly the radioactive coating was formed considerably less than 15,000 years ago. The 
lower grade of the ore in the old open pit workings is probably due to leaching at the outerop rather than to dissemination or spreading of small high-grade ore bodies as proposed by Heyl (1955).

The J. Ja mine, Montrose County, Colo,, shows the transition from unoxidized to oxidized ore at a perched water table.

\section{Dry mines with oxldized vanadiferous ore}

The dry mines with highly oxidized ore may be classified in three groups. Many carnotite deposits apparently have been oxidized in place with practically no movement of material. Some have been modified during an intermediate stage of oxidation by migration of vanadium and possibly of uranium downdip. Ore sandstone directly at the surface of the ground probably has been leached of some uranium and vanadium bj alkaline surface and ground water.

\section{Oxidation in place}

Where there is little or no catchment area to supply ground water to the ore sandstone, moist air oxidation takes place without significant migration of vanadium and uranium. The supply of ground water is sma.11 or negligible in isolated knolls, in small fault blocks along the borders of the collapsed salt anticlines, or where strata dip away from a valley wall. Examples of mines situated thus are the Rattlesnake mine in the north end of Lisbon valiey, San Juan County, Utah; severa.l mines in the Jo Dandy group along Paradox valley; and the Dolores group of mines on the bench of Atkinson Mesa above the Dolores River, Montrose Countiy, Colo.

The Rattlesnake mine in Lisbon valley had (in 1954) highly oxidized ore in dry friable sandstone. The yellow and brown ore had spotted and banded 
textures resembling those in unoxidized ore and giving the appearance of oxidation with little or no movement of material. Hewettite, the red calcium vanadate, seems to be more abundant in the ores of the Jo Dandy and Dolores groups of mines than in the ores of the Club group (see below) of mines through which oxidizing solutions probably have migrated. In general, if the vanadium-uranium ratio is high, ores that have been oxidized in place by moist air have more of the brightly colored vanadates than other ores.

The carnotite- and tyuyamunitenrich logs found in various mines appear to be the oxidized product of fossil wood partily replaced with uraninite and impregnated with montroselte. Some of these have been oxidized with very little spreading or dissemination of uranium and vanadium. The detailed wood cell structure so commonly observed in polished sections of uraninite (p1. 2A) is destroyed by volume changes dursing oxidation, and carnotite logs show only the gross feature of the wood. Onlly one instance of wood cell structure preserved in secondary minera.ls has been noted-that of a narrow rim of becquerelite around uraninfterreplaced fosstil wood at Monument No. 2 mine, Apache County, Ariza, (personal commurication, D. H. Johnson).

\section{Modification during oxidation}

Ores in strata that have a ground-water catchment area updip and that are truncated downdip by a canyon may have been modified during oxidation by migration of water-soluble vanadium and possibly selenium and other constituents, especially if the strata are moderately permeable. Vanadium is readily leached from partiy oxidized ore by water; $50-\mathrm{g}$ samples of blue-black ore (from the Bitter Creek mine, Montrose County, Colo., and the Corvusite mine, Grand County, Utah) in $500 \mathrm{ml}$ of distilled water yielded solutions 
with pH below 2 and contalined uranium as well as vanadium. Oxidizing ground water moving downdip through ore would leach vanadium from the vanadyl vanadates more easily than from the vanadium silicates. The water would be acid until neutralized by solution of carbonate cement.

The Club group of mines (Fischer, 1942, p. 386) on the bench formed by the Salt Wash sandstone member of the Morrison formation above the San Miguel Canyon at Uravan, Montrose County, Colo., are dry with chiefly oxidized ore and the ore rolls have "breakaway surfaces" The strata dip toward the canyon allowing water to drain through the more permeable sandstone beds. Higher on Club Mesa the Iasa,1le Mining Company's 260-foot shaft mine is also dry and has welledeveloped rolls in oxidized ore; a little corvusite ore and radioative hartive in mineralized logs; and some blanket-like, spotted ore with calclte cement in the deepest, least oxi.. dized portion of the mine. The bartte is costed. with radioactive daughter products, probably radium sulfate, prealpitated from recently oxidized primary ore minerals. Evaporation of molsture on certain beds of sandstane along the mine walls forms pascoite. Still higher on Club Mesa the Shattuck Denn Company's 500 foot shaft mine is moderately dry a.l though certain horizons in the Brushy Basin shale member of the Morrison formation had considerable water when the operators were sinking the mine shaft. The ore is partly oxidized with a few remnants of coffinite and montroseite and a trace of secondary yellow appearing on the joint surfaces. The ore has an undulating surface but no typical "breakaway roll surfaces." The Cougar mine in the Lower Group at Slickrock, San Miguel County, Colo., is located on a bench of Salt Wash sandstone that dips toward the Dolores River canyon and has the same struetural situation as the Club mines. Around the rim of the bench are many old adits and on top of the 
bench old open-pit workings which show mined-out rolls with "breakaway surfaces," The underground workings have numerous rolls in severa.l sand.stone lenses separated by thin clay beds. Away from the surface and ciliff face some less-oxidized patches of ore persist and locally copper sulfides and copper, lead, and silver selenides occur, and the vanadiferous ore is in the corvusite stage. Up the hill a few hundred yards from the Coigar mine is the Little Muriel shaft about 35 or 40 feet deep. In the summer of 1954 after the mine had been abandoned for a time, about a foot of water had accumulated, and seepage from a layer of corvusite ore had formed a thick coating of pascoite on the mine wall. Also alteration of selextdes had produced a pink efflorescence, the unstable monoclinic form of natzve selenium. Here is indication that water seepling through a partly oxid.tzed. deposit can transport vanadium, selenium, and probably other constitudents. Both the Cougar and Club mines are on the downdip side of areas that would feed water intermittent]y through them, spreading the vanadium and modifying its distribution. Vanadium silicate ore seems to be more abundant than vanadate ore in these mines probably because of leaching of cormstte. The ore rolls have well-developed "breakaway surfaces" that "have been accentuated during oxidation by one or more of the following processes: solution of pyrite, vanadates, and some of the carbonate cement, and volume changes due to oxidation and changes in hydration. These mines illustrate the gradation from oxidized ore near the surface to less oxidized ore back from the outcrop.

Ore sandstone directly at the surface of mesas

Where sma.1 dry mesas are capped by ore sandstone as at the Easts.lde Carrizo mines, west of Shiprock, N. Mex, the chief vanadium mineral is 
vanadium chlorite, bydromica, or other vanadium silicate mineral. The ore of light even gray color is low In uranium which is present in thinly disseminated yellow grains of tymymunte in the sandstone or as a coating of tyuyamunite on the joint surfaces below a thick caliche-like crust. Uranium seems to have been leached from these surface deposits probably by recent alkaline ground water. Hewettite probably has been leached from the surface by alkaline ground water also; only a few remnants of hewettite occur under a hard cemented sandstone bed. In the deepest part of one of the abandoned mines in the Eastside Carrofizo growp.

Other areas having vanadium silicates with very little carnotite or other vanadium minerals in ore outcrops on top of mesas or broad benches include Flat Top Mesa in the midale of the syncline south of Gateway, Colo., and another Flat Top Mesa (also called Shinarump Mesa), west-southwest of Temple Mountain, Kmery County, Utuh.

A salt crust consisting principally of sodjum sulfate, with some carbonate and other salts, accumulates near the foot of the Brushy Basin shale outerops at the Cactus Rat mines in the Thompsons district, Utah. The surface water saturated. With these salts has affected the recent oxidation of the ore in this area, causing the development of sodium vanadate, schroeckingerite, andersonite, zippeite, and other minerals not typical in vanadiferous ores.

The highly alkaline condition of the ground water and the thick salt crusts probably first developed in the Altithermal part of the Recent--a warm dry period of great caliche formation from Wyoming (Leopold and Miller, 1954) south to Texas and Mexico (A. W. Weeks, 1945)-mand have continued on a somewhat less interse scale to the present time. 
RELATIVE STABILITY AND SIZE OF OXIDIZED DEPOSITS

Because of the stability of carnotite, large oxidized deposits of carnotite have developed at shallow depth in the Colorado Plateau. In the progressive alteration of the black low-valent ores, the corvusite stage is the critical stage when the minerals are rather unstable and vanadium or uranium or both could be leached if water moved through. As soon as the carnotite stage is reached the deposit becomes relatively stable under shallow depth conditions and little happens to it until, uncovered by erosion, it reaches the caliche zone at or close to the outcrop. Then in the alkaline environment carnotite appears to be slowly leached.

During oxidation of nonvanadiferous uranium ores on the Plateau, uranyl carbonates and sulfates seem to be more common than hydrated uranyl oxides, phosphates, arsenates, and silicates. The carbonates and sulfates are the least stable (Garrels and Christ, 1955) of the secondary uranium minerals and do not accumulate to form large oxidized deposits in situ as does carnotite. The secondary minerals form around oxidjzing uraninite and spread into joint fractures or along bedding planes but do not remain if water moves through the fractures.

Preservation of nonvanadiferous deposits in a dissected plateau such as the Canyon Lands of Utah depends on local structural and sedimentary features. Ore in a channel that is parallel to the regional strike has a better chance of preservation than ore in a channel parallel to the dip, especially if the channel is in strata that dip away from a canyon wall rather than toward the eanyon. In addition to conditions favoring original deposition of ore, the prospector should consider the favorable conditions 
for preservation of nonvanadiferous ore. The Happy Jack mine on the southwest side of White Canyon is in a much more farorable situation for preserva tion of ore than the mines on the southwest end of Deer Flats where there is less cover and the strata dip toward the caryon; these are on the west flank of the Monument Jplift in San Juan County, Utah. The ore of the Hidden Splendor (Delta) mine is protected. In its location under the steeply dipping Wingate sandstone along the monocline of the southeast side of the San Rafael swell in Utah.

\section{SECONDARY ENRTCHMEFNT}

Secondary enrichment is unli.kely in most of the varadiferous yrangum ore bodies for the following reasons: 1) the ore bodies are small tahnlar or pod-like bodies with the long dimension(s) paralleli to the bedding; e) the thickness is rarely more than 25 feet and eommonly less than 10 feet; 3 ) in. moist-air oxidation little if any migration takes place; 4) oxidation of the small ore bodies is rapid; 5) carnotite the chief oxidized uranium mineral has very low solubility; and 6) the sulfide coatent of vanediferous ore is low.

Only a few nonvanadiferous uranium ore bodies in the Plateau, such as that at Happy Jack mine, Utah, have abundant sulfides and a favorable struc. ture for migration of solutions from oxidized into unoxidized ore where sooty pitchblende, chaleocite, and covellite are deposited to form a zone of secondary enrichment. The chief oxidized produets of nonvanadiferous ura.. nium ore are much more soluble than carnotite and are generally washed away rather than being redeposited. 
TTIME AND DEPITH OF OXIDATION

The oxidation of the Colorado Plateau uranium ores took place since the water table was lowered following the canyon cutting of the present erosion cycle. As the regional water table dropped, water was retained in the pore spaces of many rocks high above the main water table. This is particularly true in the fluvial-type sediments that are the common host rocks of the Plateau uranium ores. Tolman (1937, p. 156-157) states that the so-called capillary fringe zone may be much thicker above a sinking water table than above a rising water table.

Detailed study in the Uravan mineral belt shows that interbedding of shales, shaly sandstones, and lenticular sands together with a folded and faulted structure allows many varied situations with respect to perched water tables, retention of moisture, and the location of preserved unoxidized. ore. The depth to unoxidized ore ranges from a few feet to many hundreds of feet. Because of the moderately low rainfall and the wide range of permeability of the sediments some deposits have had almost no water moving through during oxidation and others have had enough to modify the deposit appreciably •

Bateman (1950, p. 265-269) states that submerged oxidized zones are common in western United States. Possibly when more detailed knowledge of the oxidation pattern of the Colorado Plateau ores is obtained, a history of fluctuating water tables may be found, but as yet no submerged oxidized zones have been recognized in Plateau ores. The irregular boundary of oxidation high above the regional water table more closely fits his description of stranded oxidized zones (Bateman, 1950, p. 265), "If the water table is depressed rapidly, oxidation may not be able to keep pace with it and the 
bottom of oxidation may become stranded above the water table." The oxidation history of the Plateau ores appears to be a one-way process following a lowered water table.

The small amount of radioactive barite found in several mines between Uravan and Paradox Valley indicates that some of the oxidation is Recent. Studies of the Ra-UU equilibrium of several high-grade carnotite and tyuyamunite samples by Stieff and Stern (personal communication) indicate that in some mines oxidation occurred during the Pleistocene.

\section{REFFRENCES}

Axelrod, J. Mo, Grimaldi, F. S., Milton, Charles, and Murata, K. J., 1951, The uranium minerals from the Hillside mine, Yavapai County, Arizona: Am. Mineralogist, v. 36, p.1-22.

Barnes, W. $E_{0}$, 1955, Hewettite and metahewettite: Am. Mineralogist, $V_{0} 40$, p. $689-691$.

Bateman, A. M., 1950, Economic mineral deposits, New York, John Wiley \& Sons, Inc., $916 \mathrm{p}$.

Breger, I. A, and Deul, Maurice, 1955, The association of uranium with carbonaceous materials on the Colorado Plateau: U. S. Geol. Survey Trace Elements Inv. Rept. 539.

Coffin, R. Co, 1921, Radium, uranium, and vanadiun deposits of southwestern Colorado: Colorado Geol. Survey Bull. 16.

Cooper, Margaret, 1953, Bibliography and index of literature on uranium and thorium occurrences in the United States, Part 1, Arizona, Nevada, and New Mexico: Geol. Soc. America Bull., v. 64, p. 197-234.

, 1954, Bibliography and index of literature on uranium and thorium occurrences in the United States, Part 3, Colorado and Utah: Geol. Soc. America Buil., v。65, p. 467-590.

Evans, H. To, Jr., 1955, Vanadium mineral alteration sequences in relation to crystal chemistry and thermodynamies (abs.): Geol. Soc. America Bul1., v. 66, p. 1556 .

Evans, H. T., Jr., and Mrose, M. E., 1955, A crystal chemical study of montroseite and paramontroseite: Am。 Mineralogist, v. 40, p. 861.875. 
Finch, W. Io, 1954, Geology of the Shinarump No. I mine, Seven Mile Canyon area, Grand County, Utah: U. S. Geol.o Survey Circ. 336.

1955, Preliminary geologic map showing the distribution of uranium deposits and principal ore-bearing formations of the Colorado Plateau region: U. S. Geol. Survey Mineral Inv. Field Studies Map MF 16。

Fischer, R. P., 1942, Vanadium deposits of Colorado and Utah: U. S. Geol. Survey Bull. 936-P, po 363-394.

1950, Uranium-bearing sandstone deposits of the Colorado Plateau: Econ. Geology, $v_{0} 45$, p. 2011 .

Fischer, R。 P., Haff, J. C., and Rominger, J. F。, 1947, Vanadium deposits near Placerville, San Miguel County, Colorado: Colorado Sci. Soc. Proc., vo 15, p. 1.15-134。

Fischer, Ro $P_{0}$, and Hilpert, I. So, 1952, Ceology of the Uravan mineral belt: U. S. Ceol. Survey Bul1. 988-A, p. 1-13.

Foshag, W. F., and Hess, F. I., 1927, Rossite and metarossite, two new vanadates from Colorado: U. S. Nat. Mus. Proc., v. 72, p. 1-12.

Friedel, C., and Cumenge, $E_{.}, 1899$, Sur une nouvelle espêce minerale, Ia carnotite: Comptes rendus $128, p .532$.

Garrels, $R_{0}$ Mo, 1953, Some thermodynamic relations among the vanadium oxides and their relations to the oxidation state of the uranium ores of the Colorado Plateaus: Am. Mineralogist, v. 38, p. 1251-1265.

Garrels, R. Mo, and Christ, C. I., 1955, Some aspects of the crystal chemistry of the oxidation of the Colorado Plateau urginium ores (abs.): Geol. Soc. America Bul1., V. 66, p. 1564.

Gross, E. B., 1955, Mineralogy and paragenesis of the uranium ores of Mi Vida mine, San Juan County, Utah: U. S. Atomic Energy Commission RME-74.

Gruner, J. W., and Gardiner, I., 1952, Mineral associations in the uranium deposits of the Colorado Plateau and adjacent regions with special emphasis on those in the Shinarump formation, Part III. Annual Report, July 1, 1951. to June 30, 1952: Atomic Energy Commission, RMO-566.

Guillemin, M. C., 1955, Une nouvelle espêce minerale: la vesignieite $\mathrm{CuRa}\left(\mathrm{VO}_{4}\right)_{2}(\mathrm{OH})_{2}$ : Comptes rendus, $\mathrm{V} .240, \mathrm{no} 24$.

Hathaway, John, 1955, X-ray diffractometer study of some vanadium silicates: U. S. Geol. Survey Irace Elements Inv. Rept. 542 .

Henderson, E. Po, 1935, Steigerite, a new vanadium mineral: Am. Mineralogist, v. 20, p. 769-772. 
Henderson, F. F., and Hess, F. $I_{0}, 1933$, Corrusite and rilandite, new mineral.s from the Utah.Colorado carnotite region: Am. Mineralogist, v. 18, p. 195-205。

Hess, F. L., 192.2, Uranimmbearing asphaltite sediments of Utah: Fing. and Mining Jour., v. 114, p. 274 .

1925, Hew and known minerals from the Utah.-Colorado carnotite region: U. S. Geol. Survey BuIl. 750, p。63-78.

1933, In Ore deposits of the western states (Lindgren volume), p. 459, Am. Inst. Mining Met. Eng.

Hess, F. L., and Henderson, E. P., 1931, Fervanite, a hydrous ferric vanadate: Am. Mineralogist, v. 16, p. 273-277.

Heyl, A. V., 1954, Zoning of the Bitter Creek vanadium-vranium deposit, Montrose County, Colorado: U. S. Geol. Survey Trace Elements Inv. Rept. 443.

Hillebrand, W. F., 1913, A danger to be guarded against in making mineral separations by means of heavy solutions: Am. Jour. Sci., 4th ser., v. 35, p. $439-440$.

.1924, Carnotite and tyuyamunte and their ores in Colorado and Jtah: Am. Joure. Sci., 5th ser., v. 8, p. 201-216.

Hillebrand, W. $F_{\circ}$, Merwin, $F_{\circ} E_{\circ}$, and Wright, $F_{\circ} E_{\circ}$, 1914, Hewettite, metahewettite, and pascoite, hydrous calcium vanadates: Am. Philos. Soe. Proe., v. 53, p。 33-54。

Hillebrand, W. Fa, and Ransome, F. I., 1905, on carnotite and associzited vanadiferous minerals in western Colorado: U. S, Geol. Survey Bull. 262, p. 9-31.

Kullerud, Gunnar, 1953, The FeS-ZnS system, a geological thermometer: Norsk geol. tidsskr., v. 32, p. 61-147.

Leopold, I. B., and Miller, J. P., 1954, A postglacial chronology for some a.lluvial valleys in Wyoming: U. S. Geol. Survey Water-supply Paper $1261,90 \mathrm{p}$.

Murata, K. J., Cisney, E. A., Stieff, L. R., and Zworykin, E. V., 1951, Hydration and base exchange properties of carnotite, tyuyamunite, and related compounds (abs.): Am. Mineralogist, v. 36, p. 323.

Phoenix, D. A., 1952, Present and past ground--water conditions in the Morrison formation in southwestern Colorado and southeastern Utah: U. S. Geol. Survey Tra.ce Elements Inv. Rept. 161.

Ritter, G. C., 1955, Ore procurement program: The Mines Mag., v. 45, p. 102. 
Roach, C. H., and Thompson, M。E, 1955, Sedimentary structures and the localization and oxidation of ore at the Peanut mine, Montrose County, Colorado: U. S. Geol. Survey Trace Elements Inv。 Rept. 5.12.

Stern, T. Wo, and Annell, C. S., 1954, A second locality of novaceki.te: Am. Mineralogist, $\forall .39, p \cdot 675-676$.

Stern, T. W., Stieff, I. $R_{0}$, Girhard, M. No, and Meyrowitz, Robert, in press, The occurrence and properties of metatyuyamunite, $\mathrm{Ca}\left(\mathrm{UO}_{2}\right)_{2}\left(\mathrm{VO}_{4}\right)_{2}{ }^{\circ}$ 3-5 $\mathrm{H}_{2} \mathrm{O}:$ Am. Mineralogist.

Stern, T. W., and Weeks, A. D., 1952, Second accurrence of bayleyite in the United States: Am. Mineraiogist, $v_{0}$ 37, p。 1058-1060,

Stieff, I. R., and Stern, T. W., 1952, Identification and lead-uranium ages of massive uraninites from the Shinarump conglomerate, Utah: Sclence, v. 115, p. 706-708.

Stieff, I. R., Stern, I* W., and Sherwood, A. Mo, 1955, Preliminary description of coffinitem-a new uranium mineral: Seience, v. 12.1, p. 608-609.

Thompson, M. E., Ingream, Blanche, and Cross, E. B., 1956, Abernathyite, a new uranium mineral of the metatorbernite group: Am. Mineralogist, v. 41, p. 82-90.

Thompson, M. E., Roach, Carl, and Braddock, William, 1956, New oceurrences of native selenium: Am. Mineralogist, $\nabla .41, p_{0}$ 156-157.

Thompson, M. E., Weeks, A. D., and Sherwood, A. M., 1955, Rabbittite, a new uranyl carbonate from Utah: Am. Mineralogist, v. 40, p. 201..206.

Tolman, C.F., 1937, Ground water, New York, MeGrawalilil Book Co, 593 p.

Trites, A. F。, Jr, and Chew, R。 T., 3d, 1955, Ceology of the Happy Jack mine, White Canyon area, San Juan County, Jtah: J. S. Geolo Survey Bull. 1009-H.

Weeks, A。 D., Cisney, E. A., and Sherwood, A. M., 1953, Montroseite, a new vanadium oxide from the Colorado Plateaus: Am. Mineralogist, V. 38, p. $1235-1241$.

Weeks, A. D., and Thompson, M. E., 1954, Identification and oceurrence of uranium and vanadium minerals from the Colorado Plateaus: U. S. Geol. Survey Bul1. 1.009-B.

Weeks, A. D., Thompson, M. E., and Sherwood, A. Mo, 1955, Navajoite, a new vanadium oxide from Arizona: Am. Mineralogist, v. 40, p. 207-212.

Weeks, A. W., 1945, Quaternary deposits of Texas Coastal Plain between Brazos River and Rio Grande: Am. Assoc. Petroleum Ceologists Bulli., V. 29, p. 1693-1720. 